\title{
Competição intrapartidária nas eleições para deputado federal: um estudo exploratório sobre São Paulo em 2014

\author{
Cíntia Pinheiro Ribeiro de Souza'
} \\ Luís Felipe Guedes da Graça
}

\section{Resumo}

Esse artigo aborda o tema da competição intrapartidária nas eleições proporcionais de lista aberta. Embora a literatura espere que as regras eleitorais brasileiras incentivem a concorrência direta por votos entre correligionários, poucos são os esforços para mensurar os níveis dessa competição. A partir de correlações de votos, por zonas eleitorais, discutimos os graus de sobreposição espacial das candidaturas dentro de quatro partidos na disputa pelo cargo de deputado federal no estado de São Paulo em 2014. Encontramos variações nos níveis de competição intrapartidária que indicam diferentes estratégias de coordenação na seleção de candidatos. Essa variedade mostra que, além dos incentivos das regras eleitorais, as respostas estratégicas dos agentes a essas regras não devem ser negligenciadas ao tratar desse tema.

Palavras-chave: Eleições. Deputado federal. Competição intrapartidária. Representação. São Paulo

\section{Introdução}

Os partidos brasileiros são tradicionalmente considerados fracos em sua atuação na arena eleitoral, principalmente nas disputas por cargos proporcionais. Essa fragilidade tem sido questionada por trabalhos mais

\footnotetext{
I Pós-doutoranda na Universidade Federal de Santa Catarina (UFSC). Doutora em Ciência Política pelo Instituto de Estudos Sociais e Políticos (IESP) da Universidade do Estado do Rio de Janeiro (UERJ).cprsouza@gmail.com

2 Professor do departamento de Sociologia e Ciência Política da Universidade Federal de Santa Catarina (UFSC). Doutor em Ciência Política pelo Instituto de Estudos Sociais e Políticos (IESP) da Universidade do Estado do Rio de Janeiro (UERJ). Ifggraca@gmail.com
}

\section{$(\infty))$ EY}

Direito autoral e licença de uso: Este artigo está licenciado sob uma Licença Creative Commons. Com essa licença você pode compartilhar, adaptar, para qualquer fim, desde que atribua a autoria da obra, forneça um link para a licença, e indicar se foram feitas alterações. 
recentes e encontra, nas mudanças trazidas pela reforma eleitoral de $2015^{3}$, um teste à capacidade dos partidos em coordenar suas açóes. Dentre as alteraçôes da lei, a mudança do art. 108 do Código Eleitoral de $1965^{4}$ passa a exigir, do candidato, um mínimo de votos nominais igual a $10 \%$ do quociente eleitoral. Essa mudança traz um custo claro para os partidos que não coordenarem sua atuação eleitoral ao angariarem votos que poderão não ser traduzidos em cadeiras. Concentrar votos em apenas um candidato ou deixar que candidatos concorram pelos mesmos votos pode gerar ineficiência na busca por cargos no Legislativo.

O objetivo deste artigo é discutir o protagonismo, ou a figuração, dos partidos na coordenação das eleiçôes proporcionais brasileiras. A ideia central a orientar este exercício é explorar a discussão sobre o tamanho da competição intrapartidária na disputa para o cargo de deputado federal. O caso analisado é o do Estado de Sáo Paulo, o distrito com a maior magnitude eleitoral - 70 cadeiras - nesse tipo de eleição. Ao explorar a intensidade dessa competição dentro de alguns partidos, buscamos discutir o quanto esses contribuem para a definição das estratégias de campanha e dos resultados eleitorais proporcionais.

Os candidatos aos cargos legislativos no Brasil têm sido vistos pela literatura como muito independentes dos partidos e das lideranças durante o processo eleitoral (MAINWARING, 1993; CAREY; SHUGART, 1995; NICOLAU, 2006; SAMUELS, 2008). Grande parte dessa visão se deve ao sistema eleitoral de lista aberta que opera no país. A existência do voto preferencial é fonte de muitas expectativas teóricas sobre o funcionamento dos partidos políticos, as coalizóes de governo e a relação entre representantes e representados. O fato de os eleitores ordenarem os nomes nas listas de candidatos eleitos de partidos e coligações cria competição intrapartidária, situando a persona do candidato, em vez de reputação partidária, como crucial para a conquista de um assento no órgão representativo. Baixa capacidade de controle de líderes partidários no processo de seleção de candidaturas e predominância de redes de financiamento ligadas mais aos candidatos que aos partidos reforçariam o caráter personalista da dis-

3 Lei $n^{\circ} 13.165$ de 2015, de 29 de setembro de 2015 (BRASIL, 2015).

4 Lei no 4.737 de 1965, de 15 de julho de 1965 (BRASIL, 1965). 
puta. As decorrências desse incentivo seriam custos baixos para decisóes que fragilizem identidades partidárias, como o estabelecimento de relações paroquialistas com o eleitorado, infidelidade partidária, migração de candidatos eleitos e fraca disciplina legislativa (MAINWARING, 1995). Parte da literatura, no entanto, tem buscado rever criticamente as hipóteses iniciais sobre como funcionam coalizóes governativas e partidos políticos no Brasil (LIMONGI; FIGUEIREDO; 1999; BRAGA 2008, BOLOGNESI, 2013). Há mais racionalidade, coordenação e equilíbrios estáveis no sistema político brasileiro do que apresentado pelas expectativas do começo dos anos 1990.

A ideia de competição intrapartidária é central nas concepções sobre como funcionam as eleiçóes legislativas no Brasil. No entanto, ela continua pouco explorada pela literatura. Carey e Shugart (1995), ao discutirem formas classificatórias de sistemas eleitorais a partir dos incentivos personalistas que promovem, usam a ideia de competição intrapartidária como um fator dicotômico, que existe quando o voto é preferencial e a lista é ordenada pelo eleitor, ou que está ausente quando a composição da lista é feita pelo partido. É essa crença de natureza dicotômica que ajuda a explicar a pouca atenção dada a medidas ou questionamentos sobre o grau dessa competição intrapartidária dentro de cada partido.

Argumentamos aqui que a competição intrapartidária precisa ser analisada como algo além de um evento meramente dicotômico. Logicamente, a competição intrapartidária existe apenas em sistemas que possuem voto preferencial, mas ela pode tomar gradaçóes diferentes. A atuação dos partidos e líderes partidários na escolha dos candidatos e de estratégias de campanhas tem efeitos diretos sobre a competição intrapartidária.

Dois candidatos competem por um voto quando apresentam suas candidaturas ao eleitor e buscam convencê-lo de que cada um deles é a melhor escolha. Assim, a competiçáo intrapartidária deve ser entendida como a disputa eleitoral entre membros do mesmo partido pelo voto de um eleitor. Na disputa eleitoral por cargos na Câmara de Deputados, os candidatos concorrem em distritos iguais aos Estados da Federação. Por se tratar de uma disputa com magnitude que varia de 8 a 70 cadeiras, para conseguir sucesso eleitoral, os candidatos precisam conquistar somente uma fraçáo 
do eleitorado. Cada candidato possui eleitores potenciais diferentes definidos por ligaçóes geográficas, temáticas ou sociais com os representados. Os partidos podem utilizar essas informaçóes sobre o eleitorado potencial dos candidatos para orientar suas nominaçóes. Caso exista intensa competição intrapartidária, no sentido que mais de um candidato do partido dispute o mesmo voto potencial, o partido estará, como um todo, empregando de forma ineficiente seus recursos. Esse cenário é prejudicial tanto ao partido quanto aos candidatos envolvidos na disputa pelo mesmo voto. Ao partido, por dispersar esforços repetidos na conquista do mesmo eleitor potencial, inflando seus custos, e aos candidatos, por verem suas chances individuais de eleição serem negativamente afetadas.

Assim, a competição intrapartidária pode ser afetada por iniciativas de coordenação dos dirigentes partidários, principalmente na formação da lista de candidatos. Estratégias eleitorais coletivas, a ideologia dos partidos e a escolha de participar em uma coligação com partidos maiores ou menores são fatores que influenciam na competição intrapartidária quando considerada como um fenômeno mais amplo que o direito de escolha do eleitor. Incentivos institucionais importam, mas as maneiras pelas quais os agentes reagem e lidam com as regras acarretam consequências. A literatura que foca exclusivamente em incentivos das regras eleitorais perde de vista o aprendizado dos atores envolvidos em jogos que, como os eleitorais, se repetem periodicamente.

Esse artigo busca verificar graus de competição intrapartidária usando sobreposição espacial entre os candidatos. Ele se divide em três partes e conclusão. Após essa breve introdução, a primeira parte apresenta, de forma resumida, o debate sobre as expectativas da literatura acerca de sistemas eleitorais e seus impactos nos partidos políticos. A segunda parte discorre sobre competição e coordenação intrapartidária no Brasil. A terceira parte se dedica à abordagem mais empírica na qual discutimos e apresentamos uma forma exploratória de medir competição intrapartidária que considera a correlação das votaçóes entre os candidatos por zona eleitoral. Por fim, concluímos o artigo com alguns apontamentos acerca de pesquisas futuras sobre o tema. 


\section{Sobre sistemas eleitorais e partidários}

A literatura sobre sistemas eleitorais e partidários se preocupou principalmente em compreender como as variáveis institucionais associadas às regras eleitorais e à conformação dos sistemas partidários influenciam na governabilidade dos países. Os atritos gerados pela dualidade de objetivo das eleiçóes gerais - formar governo e gerar representação - percorrem todo o debate sobre sistemas eleitorais e sistemas partidários. Visóes majoritárias e proporcionais sobre as eleiçóes como o instrumento da democracia não compartilham das mesmas expectativas (POWELL, 2000). Em geral, a governabilidade - ou clareza de responsabilidade sobre as ações - varia inversamente à representatividade de um sistema. Por isso, pode-se afirmar que, por um lado, as regras eleitorais que promovam resultados mais proporcionais e fragmentação partidária contribuem para o aumento da representatividade e diminuem a governabilidade (eficiência) dos sistemas políticos. Por outro lado, quando os resultados são menos proporcionais e existe menos fragmentação partidária, gera-se mais governabilidade à custa de uma diminuição da representatividade.

Há um esforço para classificar os sistemas eleitorais em função dos incentivos e efeitos esperados a partir deles. No tema da construção das listas partidárias, separam-se os sistemas eleitorais entre os que promovem mais personalismo e aqueles que geram mais partidarismo na atuaçáo dos representantes. Conforme a classificação ordinal de Carey e Shugart (1995), três critérios são chave para compreender os sistemas eleitorais e seus incentivos para os políticos construírem ligaçóes centradas no partido ou no indivíduo. O primeiro critério trata do acesso à lista de candidatos do partido. Esse controle se refere tanto ao controle exercido sobre o acesso ao direito de figurar na lista de candidatos quanto sobre a ordenaçáo dos candidatos na lista. A ausência de preordenação dos candidatos de uma lista sob sistema proporcional permite, por exemplo, que haja competição entre candidatos de uma mesma legenda. Os autores propóem que o controle pode ser estrito se os líderes selecionam os candidatos e preordenam a lista como nos sistemas de lista fechada; intermediário, se os líderes selecionam a lista mas não a ordenam; e precário, se os líderes não selecionam os candidatos e tampouco os ordenam - como na seleção via primárias. Samuels 
(2008) observa, no Brasil, um processo que reforça a seleção de candidatos com perfil mais focado em si próprios. Como, segundo o autor, existiria um processo de nominação da lista de candidatos descentralizado e com pouco controle das lideranças, as ligaçóes entre candidatos e partidos seriam fracas.

O segundo critério de Carey e Shugart (1995) mensura se o esforço conjunto dos candidatos de um mesmo partido na busca por votos afeta, de alguma forma, a sorte do partido na quantidade de cadeiras que recebe por mecanismo de transferência de votos. Nos sistemas que possuem transferência, os votos recebidos pelo candidato de um partido específico contribuem também para o número de cadeiras ganho pelo partido como um todo. Assim, os votos do candidato são conjugados com os votos do partido se esses são primeiramente somados aos votos de seus companheiros de legenda como um conjunto que determina quantas cadeiras recebe o partido. A fórmula brasileira prevê essa conjugaçáo dos votos de candidatos e partidos. Em outros sistemas, os votos do candidato são conjugados parcialmente aos votos do partido se os votos do candidato são somados apenas aos de listas ou candidatos específicos dentro do partido para determinar as cadeiras que o partido tem direito. Assim, um candidato pode ser eleito com a ajuda dos votos de eleitores que o preferiram em segundo lugar de uma lista, por exemplo. Já a ausência de conjugação dos votos do candidato com os votos do partido implica que o candidato deverá obter por conta própria os votos necessários para ser eleito. $\mathrm{O}$ exemplo clássico dessa fórmula é o voto único não transferível (SNTV), conhecido no Brasil pela alcunha de "Distritão".

O terceiro critério captura a escolha do eleitor, se esses escolhem um partido, múltiplos candidatos ou apenas um candidato específico de um partido. Na situação em que a escolha se dá por um partido, espera-se que o peso da reputação partidária seja muito maior que no caso de o eleitor possuir a opção de também escolher o nome do candidato.

Da combinação desses três critérios, resultam sistemas eleitorais que variam dos sistemas de lista fechada em um turno - aquele que mais incentiva o partidarismo - ao voto único não transferível sem seleção de candidatos, ou que mais incentiva o personalismo. Os achados dessa literatura, 
no entanto, enfrentam críticas. Santos (2006), por exemplo, não encontra efeitos claros dos modelos de listas eleitorais na competição partidária e no desempenho institucional.

Por um lado, os sistemas eleitorais que geram incentivos para um partidarismo maior dos representantes sáo vistos de forma positiva porque, em tese, partidos fortes trazem mais inteligibilidade para o processo decisório e diminuem os custos de governabilidade. Quando as lideranças dos partidos conseguem controlar os representantes de maneira que esses últimos sejam disciplinados na arena parlamentar, espera-se que haja mais disciplina e lealdade partidária, além da predominância de políticas programáticas voltadas para as questóes nacionais (COX, 1987).

Por outro lado, os sistemas eleitorais que geram incentivos para um personalismo maior dos representantes são vistos de maneira negativa. Em tese, o personalismo é sinônimo para partidos fracos, pois as lideranças têm pouco ou nenhum controle sobre os representantes. Se os líderes são fracos, torna-se mais difícil resolver problemas de ação coletiva entre os representantes do partido porque, sem a coerção do líder, suas preferências incongruentes podem levar os representantes à indisciplina e até mesmo à baixa lealdade partidária e à troca de partido. $\mathrm{O}$ personalismo também pode gerar incentivos para uma atuação do tipo paroquialista (CAIN, FEREJOHN; FIORINA, 1987, SHUGART; CAREY, 1992). Esse tipo de atuação é percebido como danoso para a governabilidade porque aumentaria os custos de negociação entre o Executivo e o Legislativo já que essa última se daria em bases individualizadas. Quando essas características estão associadas a sistemas multipartidários, o tom pessimista se torna ainda mais forte (MAINWARING, 1993, 1997).

O sistema eleitoral proporcional de lista aberta, adotado no Brasil, é enquadrado como forte empecilho para a coordenação da lista de candidatos. Bergman, Shugart e Watt (2013) indicam que, nesse sistema, há alinhamento entre os incentivos de candidatos individuais e de partidos que buscam maximizar a quantidade de cadeiras ganhas no Legislativo. Para os autores, a formação de um pool partidário de votos para a distribuição de cadeiras faz com que um partido seja indiferente a distribuição interna de votos e veja cada candidato potencial como capaz de trazer mais 
votos para o partido. Para eles, há incentivos para os dirigentes partidários estabelecerem uma competição intrapartidária no estilo laissez-faire. Há incongruência nessa premissa dos autores que descarta a atuação dos dirigentes para coordenar a lista de candidatos em sistemas proporcionais de lista aberta. Partidos dependem da votação conjunta dos candidatos para o cálculo de atribuição de cadeiras e é do interesse dos dirigentes aumentar a quantidade de votos que o partido recebe, já que isso lhes dá maior poder de negociação com o governo na formação de coalizóes. No caso do Brasil, a quantidade de cadeiras do partido no Legislativo também afeta o acesso a financiamento eleitoral público que é composto por fundos e por tempo de rádio e televisão. Uma política de livre concorrência na competição intrapartidária pode gerar problemas para partidos e candidatos quando existe a disputa entre correligionários pelo mesmo voto. Para o partido, essa disputa significa que esforços de campanha estão sendo desperdiçados no mesmo eleitor potencial. O partido poderia receber esse mesmo voto com menos recursos, o que permitiria realocar esforços no aumento da quantidade total de votos do partido. Para o candidato, a competição intrapartidária, no sentido apresentado acima, dificulta a maximização de seus votos e pode afetar diretamente a sua posição na lista do partido ${ }^{5}$. A negligência, a priori, acerca do papel de coordenação, dos dirigentes partidários, na formação da lista, implica na expectativa de que esses atores não buscarão remediar ineficiências, do ponto de vista partidário, na busca pelo sufrágio.

No caso brasileiro, a falta de incentivos eleitorais para coordenação seria agravada por outras questôes. A combinação de representação proporcional e barreiras baixas para a obtenção de representação (definidas pelo quociente eleitoral) resultariam em alta fragmentação partidária (MAINWARING, 1997, p. 68). Além disso, o federalismo seria uma dificuldade ${ }^{6}$ a mais para

5 Samuels (200I) encontra que o aumento na qualidade da competição intrapartidária - ou seja, na qualidade dos competidores no interior do partido - gera aumento dos gastos de campanha.

6 Chhibber e Kollman (2004) contribuem para a qualificação do argumento de Mainwaring sobre a influência do federalismo sobre a arena eleitoral, porque aqueles autores enfatizam que a agregação dos votos e a nacionalização dos partidos estão relacionadas diretamente com a percepção de centralização das políticas públicas. "Quando existe descentralização e as lideranças regionais barganham muito com as nacionais, os eleitores acabam desejando que seus partidos regionais alcancem representação nacional; enquanto haja, de outro modo, centralização, os eleitorais e os candidatos percebem os benefícios de seus partidos regionais se ligarem, em cooperação, junto aos partidos nacionais para influenciar escolha do presidente e obter recursos/ políticos dado o protagonismo da União nas políticas econômicas" (CHHIBBER; KOLLMAN, 2004, p. 182). 
as lealdades partidárias porque os políticos acabariam sendo mais leais aos interesses de seu estado, que também é seu distrito eleitoral, do que à ideologia do partido (MAINWARING, 1997, p. 83). A fraqueza dos partidos brasileiros residiria justamente na incapacidade de coordenação entre suas executivas estaduais e sua executiva nacional de maneira a dar coerência às ações. Como as eleições proporcionais para a Câmara acontecem em distritos eleitorais que coincidem com os limites geográficos de cada estado da federação, as lideranças políticas estaduais costumam ter a prerrogativa de escolher os candidatos da lista do partido para a disputa no distrito. Sem a existência de prévias internas nos partidos com os filiados para escolher os nomes das listas, as convençóes acabariam por ter caráter meramente homologatório (NICOLAU, 2006, p. 695). Esse cenário de pouco controle gera a expectativa de falta de coordenaçáo, o que reforça a percepção de prevalência do personalismo e da ineficiência da lista como mecanismo eleitoral.

Essa expectativa, no entanto, desconsidera problemas informacionais que justificam a delegação do processo de seleção das executivas partidárias nacionais para as executivas partidárias estaduais. Ambas compartilham o objetivo similar: obter mais votos e conseguir mais cadeiras. Para isso, precisam contar com bons candidatos e estratégias eleitorais eficientes na distribuição de recursos. É intuitivo que as executivas nacionais deleguem às executivas estaduais o papel de selecionar os nomes da lista, até mesmo pela proximidade ao distrito dos líderes do partido no estado. O conhecimento local acerca da dinâmica política é útil para evitar sobreposição geográfica ou temática de candidatos. Por isso, essa delegação pode ser vista em termos de coordenação descentralizadora em vez de simples fraqueza ou omissão dos dirigentes nacionais. As executivas nacionais diminuem os custos de informação para decidir quais os melhores nomes e as executivas estaduais podem influir nesta escolha para melhor resguardar os interesses regionais. Isso não significa que os políticos, uma vez eleitos, vão considerar estritamente os interesses regionais na arena parlamentar. Há evidências em favor da atuação mais partidária que regional dos representantes na Câmara dos Deputados (CHEIBUB; FIGUEIREDO; LIMONGI, 2009). 
Estamos cientes de que o argumento da delegação decisória da lista para a executiva partidária estadual como forma de diminuir os custos de informação envolvidos no processo de seleção de candidatos coloca em um mesmo patamar partidos mais estruturados no sentido institucional em alguns estados e lideranças personalistas que controlam instâncias partidárias estaduais. Independentemente de como a seleção é feita em nível local, a partir de processos partidários institucionalizados ou pela escolha de uma liderança personalista local, esperamos que a descentralização traga ganhos informacionais para o processo.

Sobre a arena parlamentar, os estudos da área têm mostrado que a expectativa de partidos fracos na arena eleitoral não se traduz em partidos fracos também na arena legislativa. Nesta última, o que se vê é coordenação e coerência partidária na atuação dos representantes (FIGUEIREDO; LIMONGI, 1995, 1999; LIMONGI; FIGUEIREDO, 1995; FOWERAKER, 1998).

\section{Competição e coordenação na arena eleitoral brasileira}

As instituiçóes que reforçam a capacidade de coordenação dos partidos políticos fora da arena legislativa se constituem como uma agenda de pesquisa em desenvolvimento, em particular para os esforços revisionistas de teses sobre a fraqueza dos partidos (SHUGART; CAREY, 1992; CAREY; SHUGART, 1995; MAINWARING, 1993, 1995, 1997; NICOLAU, 2006).

Alguns estudos já são capazes de mostrar padróes de coordenação partidária. Guarnieri (2011) apresenta a existência de estruturas partidárias no Brasil fora da organização legislativa e o funcionamento formal dessas últimas de baixo para cima por meio de convençóes. Os partidos variam na quantidade de estruturas e diretórios que possuem e de mecanismos - por exemplo, as comissóes provisórias -, e estes são utilizados pelas lideranças para centralizar decisóes da vida partidária. A quantidade de comissóes provisórias é usada pelo autor como proxy de centralização de poder no interior dos partidos, indicando maior capacidade das lideranças controlarem o processo intrapartidário. Isso cria a situação em que partidos com estruturas internas mais estáveis, como diretórios, possuem maior descentra- 
lização decisória, o que pode dificultar a coordenação, enquanto partidos com maior quantidade de estruturas provisórias têm processos decisórios mais centralizados.

Braga (2008) e Bolognesi (2013) discutem o processo de seleção de candidatos para cargos legislativos dentro dos partidos brasileiros. Braga (2008) ressalta a exclusão de atores que não sejam dirigentes partidários do processo de seleção. Esses últimos controlam o acesso à lista, escolhida por órgão executivo do partido ou por líderes partidários e homologada em convençóes estaduais. Não obstante, esses dirigentes também ordenam a lista de maneira informal ao distribuírem desigualmente recursos como o acesso ao fundo partidário e ao tempo de televisão. Já Bolognesi (2013), observando o grau de democracia e inclusão no processo de seleção, encontra variaçóes entre os partidos, mas também reforça que os responsáveis por selecionar os candidatos (selectorate) são líderes e delegados partidários. Essa centralidade é indicativa de que existe um mecanismo de controle partidário através da formação da lista de candidatos.

No campo eleitoral, Braga e Amaral (2013) destacam o papel dos partidos no controle do processo de seleção de candidatos de forma estratégica na busca de uma lista de pleiteantes viável eleitoralmente. Segundo os autores, são evidências dessa composição estratégica a não utilização de todas as candidaturas possíveis - contradizendo as expectativas de Bergman, Shugart e Watt (2013) -, a utilização de candidatos "puxadores" de votos e a organização da lista considerando critérios geográficos e de diversidade social. Graça e Souza (2014), assim como Avelino, Biderman e Barone (2012), apresentam indícios de articulações estratégicas partidárias nas disputas proporcionais. Avelino, Biberman e Barone (2012) mostram que vitórias dos partidos para o cargo de prefeito melhoram as votaçóes do partido em eleiçóes proporcionais que acontecem nos dois anos seguintes. Já Graça e Souza (2014) mostram como o caráter alternado das eleiçóes municipais e estaduais/nacional permite aos partidos lançarem candidatos a prefeito que, mesmo sem grandes chances de sucesso eleitoral, conseguem tirar benefícios da exposição garantida pela campanha posteriormente. Expor-se como candidato a prefeito, mesmo sem sucesso, traz retornos eleitorais para eleiçóes proporcionais futuras. 
Em relação aos diagnósticos de personalismo e competição intrapartidária acirrada do sistema eleitoral brasileiro, é preciso compreender que, embora as eleiçóes proporcionais incentivem o personalismo pela possibilidade de escolha do nome do candidato pelo eleitor, o pool partidário dos votos individuais dos candidatos e a seleção dos candidatos da lista, apesar de não ordenada, pelos dirigentes partidários, serve como forma de contrabalancear esses incentivos.

A expectativa de que haja competição intrapartidária entre os candidatos de uma mesma lista partidária merece mais atenção. Esta se fundamenta no fato de que a lista é aberta e, ainda que exista pool partidário dos votos individuais do candidato para definir a quantidade de cadeiras do partido, a ordenação dos candidatos eleitos se dá em função de sua votação nominal. É por isso que se prevê competição intrapartidária entre os candidatos de uma mesma legenda. As percepçóes dessa competiçáo se tornam mais fortes quando consideramos que a lei faculta aos partidos lançarem candidatos até 1,5 vezes o número de cadeiras a serem ocupadas no distrito (conforme a Lei das Eleiçôes de 1997) cuja magnitude ${ }^{7}$ varia entre oito e 70 cadeiras.

Essa perspectiva de competição intrapartidária, no entanto, não considera que a montagem da lista de candidatos pelo partido, feita por dirigentes que agem de forma racional, deve ter um objetivo: transformar o máximo de votos potenciais em candidatos do partido em votos depositados na urna. Se há influência dos dirigentes partidários na montagem da lista, a eficiência na transformaçáo de votos potenciais em votos depositados deve ser o seu motor principal. A influência desses atores na composiçáo de governos ou no papel de oposiçáo depende da quantidade de cadeiras que seu partido tem. Essa última também afeta o recebimento de recursos financeiros diretos e indiretos (tempo de rádio e TV) para eleiçóes futuras.

Assim, os dirigentes partidários devem se preocupar não só com a seleção dos candidatos como forma de controle sobre a atuação legislativa deles, mas também com a estratégia eleitoral de seu conjunto de

7 A magnitude dos distritos, inclusive, é tomada como indicador capaz de aumentar a competição intrapartidária (SILVA, 2017). 
candidatos. Não basta selecionar os candidatos por seus atributos pessoais ou dedicação ao partido. Para maior eficiência eleitoral do partido como um todo, os candidatos também devem ser selecionados de forma a acomodar no distrito nomes que somem mais votos em vez de dividir o eleitorado da legenda. Por isso, os líderes dos partidos deveriam selecionar pleiteantes levando em consideração a diversidade social dos candidatos e de suas propostas (mulheres, negros, ambientalistas), privilegiar nomes com prestígio em setores específicos do eleitorado (sindicalistas, ativistas de movimentos sociais, líderes religiosos, entre outros), e, finalmente, as diferentes regióes do distrito para evitar superposição de candidatos (NICOLAU, 2006, p. 695).

Caso o eleitor realmente fosse apresentado a todos os candidatos envolvidos na campanha e esses competidores percorressem todas as cidades do estado, a expectativa de alta competição intrapartidária seria razoável. $\mathrm{Na}$ realidade, a chance de um eleitor ter contato com uma candidatura depende de uma série de fatores que a literatura clássica não considera na construção da expectativa de competição intrapartidária: a distribuição geográfica, temática e identitária das candidaturas. $\mathrm{O}$ vínculo entre candidato e eleitor, consumado pelo voto depositado na urna, é feito a partir, principalmente, de apelos que envolvem uma oferta de representação localizada, temática ou identitária. Os políticos sabem que a chance de receber o voto de um eleitor aumenta quando esses se identificam com alguma dessas características que o candidato busca representar. $\mathrm{O}$ julgamento do candidato sobre a chance de transformar votos potenciais em votos na urna guia as escolhas de como utilizar os recursos escassos que possui para sua campanha. Candidatos têm diferentes eleitores-alvo. É por essa razão que não observamos políticos que possuem história ligada a uma parte do estado fazendo campanha muito longe dali, não vemos candidatos conservadores evangélicos fazendo campanha em passeatas LGBT ou candidatos ligados a sindicatos fazendo campanha em bairros de classe alta. $\mathrm{O}$ voto se disputa na rua, mas nos locais onde se pode encontrar seu público-alvo.

Estudos de geografia eleitoral têm mostrado que a votação da maioria dos candidatos se caracteriza por padróes concentrados de votação, muitas vezes referentes a um conjunto de municípios que compóem um território mais restrito que a área de todo o distrito, que no caso das eleiçóes 
legislativas é o estado (AMES, 2003; CARVALHO, 2003; TERRON, 2009). ${ }^{8}$ Embora a unidade de competição eleitoral proporcional seja o estado, é comum a conformaçáo de subdistritos informais dos candidatos? A dificuldade, e mesmo a ineficiência, de fazer campanha em todo o estado leva os candidatos a procurar seus eleitores por cortes sociais ou geográficos. Silva (2017), inclusive, indica que o aumento da magnitude dos distritos, ou seja, mais vagas em disputa, reforça a concentração de votos dos pleiteantes.

Há outros indicadores, além da concentração territorial de votos, que podem ajudar a identificar estratégias coletivas de campanha, o que relativizaria a competição intrapartidária como regra no Brasil. Braga e Amaral (2013) trabalham com a hipótese de que os partidos vêm reduzindo estrategicamente o número de nomes na lista mesmo que a regra permita apresentar um número grande de candidaturas. Partindo do pressuposto de que os líderes controlam a seleção dos nomes, os autores defendem, através de uma tipologia de candidatos (bons de votos e supercandidatos), que os partidos têm buscado concentrar recursos nas candidaturas com potencial de angariar votaçóes expressivas.

Os partidos pequenos ou coligados podem usar de coordenação interna para favorecer apenas um nome com maior potencial de votação no horário eleitoral gratuito, por exemplo, como estratégia eleitoral coletiva. Partidos pequenos usam de coligaçóes proporcionais para conseguir cadeiras nas casas legislativas municipais, estaduais e federal. Esse é o caso do Partido Comunista do Brasil (PCdoB) que, reiteradamente, fez alianças com o PT com o objetivo de ultrapassar o quociente eleitoral e conseguir eleger deputados federais em diversos estados. Essa estratégia reforça o papel do

8 Apenas alguns candidatos com características específicas costumam ter potencial para angariar votos de maneira mais dispersa, quiçá em todos os municípios do distrito (ex-secretários de governo costumam obter votação mais dispersa segundo Ames (2003). Celebridades, ex-atletas, comunicadores, representantes de entidades de classe e líderes religiosos também têm potencial para arregimentar votos dispersos, enquanto a maioria dos candidatos obtém votação de maneira concentrada, estratégia essa que pode lhes poupar recursos de campanha, por exemplo (SOUZA; GRAÇA, 20I2).

9 A ideia de subdistritos informais aqui é utilizada para reforçar o fato de que os próprios candidatos consideram possuir um território menor que o estado no qual seus votos estão distribuídos. Não se trata essa ideia de subdistritos informais como ausência de competição interpartidária da forma como Silva (2013) critica a literatura. 
partido na formação da lista, já que requer que os votos do partido sejam concentrados em poucos candidatos para que esses sejam eleitos. Samuels (1997) levanta essa hipótese de concentração de recursos em candidatos de maior potencial ao tratar do PT. A estratégia de concentrar recursos em um candidato pode ser ótima do ponto de vista eleitoral ainda que o apelo seja personalista em sua essência. Tais candidatos podem servir como porta-vozes do partido, destacando a posição da legenda acerca de temas importantes, ou podem apenas destacar sua reputação e seus atributos pessoais. Neste último caso, o lema principal do candidato Enéias Carneiro do Prona, "Meu nome é Enéias", é um bom exemplo dessa personalização.

A existência de candidatos com diferentes eleitores-alvo abre, ao partido, a possibilidade de criar diferentes combinaçóes de candidaturas que sejam estratégicas para os objetivos eleitorais do partido. Esse último pode escolher disputar ou não diferentes grupos a partir da lista que compóe. Essa estratégia de lista pode envolver candidatos de potenciais diferentes, assim como recortes territoriais, temáticos e identitários diversos.

Por um lado, partidos podem apresentar listas de candidatos com perfis muito semelhantes, colocando esses na disputa pelos mesmos eleitores potenciais. Esse cenário deve ser justamente classificado como alta competição intrapartidária, já que, para conseguir maximizar o potencial de seus votos nos eleitores mais adequados ao seu perfil, um candidato deve retirar votos de um correligionário. Do ponto de vista partidário, essa possibilidade indica aplicação ineficiente de recursos, ao passo que ambos usarão tempo e dinheiro na busca pelo mesmo voto, o que inflaciona desnecessariamente os custos. Do ponto de vista dos candidatos, a existência de outro pleiteante do mesmo partido pelo mesmo eleitorado-alvo dificulta a ambos participarem em plena capacidade na disputa pelo topo da lista partidária.

Por outro lado, o dirigente partidário pode construir uma lista de candidatos na qual não existam sobreposiçôes de eleitor-alvo entre candidatos. Nesse cenário, os pleiteantes do partido se veriam sem concorrentes internos na busca por eleitores, tendo apenas que vencer candidatos com perfis similares de outros partidos. Dessa forma, uma competição intrapartidária, pela existência dessas segmentaçóes comuns no eleitorado, poderia ser transformada em uma competição menos atroz. A necessidade 
de ocupar o topo da lista ainda persiste; mas, nesse cenário, seria possível aos candidatos envolvidos maximizar seus votos potenciais com o menor ruído interno possível. Para o partido, esse cenário de menor competição entre seus candidatos é preferível, já que evita a multiplicação de gastos na disputa pelo mesmo voto potencial. Para o candidato, esse cenário reduz a possibilidade de que sua posição na lista seja diminuída por fatores que poderiam ser controlados, o que pode facilitar o alcance de seu objetivo: o cargo ou a demonstraçáo de força eleitoral para outras disputas.

A competição intrapartidária, então, deve ser considerada como um fenômeno gradativo. Quanto mais a lista partidária apresentar candidatos que se sobrepóem nos perfis de eleitores potenciais, mais ineficiente ela será. Nesse caso, o partido estará lançando candidatos para disputar votos de perfil igual, multiplicando os esforços para conseguir atingir esses votos. Essa configuração, na nossa compreensão, deve ser classificada como alta competição intrapartidária. Quanto menor for a sobreposição geográfica, temática ou identitária de candidaturas, mais eficiente, do ponto de vista do partido, será a lista; e esse fato deve ser classificado como baixa competiçáo intrapartidária. Ou seja, mesmo em um sistema no qual o eleitor define a ordem dos candidatos que iráo ocupar as cadeiras do partido, esse último ainda possui o desafio de montar a lista de nomes que consiga equilibrar, de forma positiva, a quantidade de votos recebidos e de esforços dispendidos.

Partidos e lideranças partidárias controlam a lista de candidatos (BRAGA, 2008, BOLOGNESI, 2013). A regra da candidatura nata não existe mais. $\mathrm{E}$, ainda que as lideranças se sintam pressionadas a dar espaço para aqueles que já possuem cargos eletivos buscarem a reeleição, há sempre, à disposição de uma liderança hábil, o recurso de trabalhar com as movimentaçóes dentro do partido em torno das ambiçóes progressivas e regressivas dos políticos.

\section{Análise empírica}

Para discutir em que nível realmente ocorre competição intrapartidária, esse artigo analisa a eleição para deputado federal do estado de Sáo Paulo em 2014. Essa é uma análise, sobretudo exploratória, que utiliza 
grades de correlaçôes das votaçôes dos candidatos por zona eleitoral para encontrar a competição intrapartidária esperada pela teoria. Portanto, tratamos da sobreposição geográfica das candidaturas. Há, ainda, as dimensóes temática e identitária que não serão tratadas sistematicamente nesse primeiro esforço, apesar de serem abordadas na discussão de exemplos. A escolha do estado de São Paulo como caso se deve a ele ser o que possui maior magnitude eleitoral, com 70 vagas para deputado federal em disputa, permitindo aos partidos lançar listas que possuem diversos nomes. Esse cenário seria aquele que geraria mais dificuldades ao partido para coordenar sua lista. Distritos com magnitudes maiores aumentam a proporcionalidade dos resultados (COX, 1991) e trazem mais competidores para a disputa eleitoral (LAGO, 2009). Além disso, como apresenta Silva (2017), a magnitude dos distritos seria um indicador de maior competição, inclusive, intrapartidária.

A escolha do uso das correlaçóes dos votos de cada candidato por partido nas zonas eleitorais deve ser justificada. Essa medida busca lidar com dois problemas: primeiro, usar agregaçóes territoriais que nos permitam ver competição dentro de grandes municípios e, segundo, compreender, de forma resumida, se há competição intrapartidária no sentido que dois candidatos tendem a ter mais ou menos votos nas mesmas zonas eleitorais. Medidas que utilizam o munícipio como base, como no caso dos cálculos de número efetivos de candidatos, muitas vezes obscurecem ou exacerbam disputas eleitorais espaciais em município maiores. Nesse sentido, o uso das zonas eleitorais pode ser benéfico. Essas são unidades gerenciadas por cartórios eleitorais que podem conter de parte de um munícipio a um conjunto de munícipios. No estado de São Paulo, em 2014, havia 425 zonas eleitorais. Em termos de número de eleitores, a menor zona eleitoral foi uma das sete zonas eleitorais do munícipio de Marília (2.019 votos) e a maior foi uma das 85 zonas eleitorais da cidade de São Paulo (201.476 votos).

O uso da correlação nos permite verificar se realmente existe competição intrapartidária nas mesmas zonas eleitorais e o grau dessa competição entre candidatos específicos. Caso haja candidatos com perfis de votaçóes muito similares - ou seja, que recebem mais votos que a própria média nas mesmas zonas eleitorais -, esperamos que eles possuam uma correlação alta e positiva entre seus votos. Caso a competição intrapartidária seja de fraca 
a moderada, esperamos que a correlação entre os votos, por zona eleitoral, exista, mas seja fraca. E, no limite, se existir forte coordenação espacial entre as candidaturas, esperamos uma correlação negativa entre as votaçóes dos candidatos, ou seja, que um tenha mais votos nos locais em que o outro tenha menos votos. A análise usando a correlação ${ }^{10}$ das votações é interessante porque considera, no seu cálculo, as médias dos votos de cada candidato, permitindo comparar nomes com alta e baixa votação, além de permitir identificar individualmente os pares de candidatos que possuem alta correlação nas suas votaçôes. Dividimos os valores possíveis das correlaçôes em cinco categorias. Correlações entre -,2 e 0,2 foram consideradas fracas, entre 0,2 e 0,6 , ou -0,2 e -0,6, foram consideradas moderadas, já as correlaçóes acima de 0,6 ou abaixo de $-0,6$ foram consideradas fortes. $\mathrm{O}$ sinal indica se os votos dos candidatos andam atrelados no sentido de aumentarem ou diminuírem juntos (correlação positiva), ou o contrário, quando um aumenta o outro diminui (correlação negativa). Essas categorias expressam um critério rígido do que seria uma correlação fraca ou ausente porque os valores escolhidos como limite são conservadores.

A forma de agregar as correlaçôes em torno de uma medida partidária é uma das questóes metodológicas a serem discutidas. Escolhemos aqui duas formas de apresentar esses dados. A primeira delas mostra quantos candidatos estavam envolvidos em correlaçóes positivas moderadas e altas. Essa medida indica a população de candidatos que enfrentou alguma forma de competição entre correligionários. Esses dados são apresentados também ponderados pelo total de candidatos do partido. Essa primeira forma de apresentar os dados é mais intuitiva, porque ajuda a compreender quantos dos pleiteantes encontraram competidores dentro da própria sigla. Essa maneira de apresentar os dados, no entanto, não considera que um candidato pode ter correlaçóes moderadas ou fortes com mais de um candidato. Para lidar com isso, a segunda forma de apresentar traz também a quantidade de pares de correlaçôes entre candidatos que possuem correlaçôes positivas moderadas ou fortes. Para oferecer uma informação comparável entre partidos, ponderamos esse número pelo total de pares

10 Utilizamos aqui a correlação de Pearson $=\frac{\text { Covariăncia }(X, Y)}{\sqrt{\text { Variáncia }(X) * \text { Variäncia }(Y)}}$. Sendo $x$ e y as votações de dois candidatos por zona eleitoral. 
de correlaçôes existentes ${ }^{11}$. Essa perspectiva de apresentar os dados enfatiza quantos pares de candidatos tiveram conflitos em relação ao universo de competição possível entre pares de candidatos do partido.

Para verificar a competição intrapartidária, apresentamos dados dos quatro partidos que elegeram mais deputados federais pelo estado de São Paulo em 2014 - o Partido da Social Democracia Brasileira (PSDB) com 14 deputados, o Partido dos Trabalhadores (PT) com 10 deputados, o Partido Republicano Brasileiro (PRB) com oito deputados e o Partido da República (PR) com seis deputados ${ }^{12}$. A escolha por esses partidos contempla uma diversidade de cenários estratégicos para os candidatos uma vez que PSDB e PT concorreram coligados com outros partidos e são legendas com organização partidária estruturada, ao passo que PR e PRB concorreram sem coligação e dependentes de puxadores de voto em suas legendas. ${ }^{13}$

A prática da coligação implica um cálculo maior por parte do dirigente partidário para a coordenaçáo da lista porque, uma vez coligados, o pool partidário dos votos e a ordenação nominal da lista se realiza com todos os outros candidatos da coligação. Por essa razão, ao montar a lista, os dirigentes de partidos coligados devem buscar um equilíbrio no lançamento das candidaturas. Náo devem lançar nomes em excesso, pois, assim, podem correr o risco de pulverizar a votação nominal de seus candidatos tornando-os mal posicionados na lista da coligaçáo como um todo. Tampouco devem permitir uma concentração muito alta de votação na figura de puxadores de votos porque os votos excedentes ao quociente eleitoral beneficiarão todos os nomes da coligação, independentemente do partido. Já para dirigentes de partidos não coligados, a concentração de votos em puxadores de votos ou a pulverização não prejudicam o pool partidário dos

II Esse valor é dado pela combinação da quantidade de candidatos par a par sem repetição.

12 Os dados das bancadas na eleição foram consultados no site da Câmara dos Deputados, na data de 16 de novembro de 2018, e estão disponíveis neste link: http://www2.camara.leg.br/deputados/liderancas-partidarias/ bancadas/bancada-na-eleicao.

I3 O PSDB concorreu coligado com o Democratas (DEM) e o Partido Popular Socialista (PPS); já o PT concorreu coligado com o PCdoB. O PR contava com a candidatura à reeleição de Tiririca que havia sido o candidato mais votado na eleição de 2010, com mais de 1,3 de milhões de votos, e o PRB tinha Celso Russomanno, que havia liderado toda a disputa no primeiro turno para a prefeitura de São Paulo em 2012 e terminou em terceiro lugar com 1,3 milhões de votos. 
votos para a definição das cadeiras, especialmente em 2014, quando não havia ainda a regra de desempenho individual dos candidatos relativos a $10 \%$ do quociente eleitoral.

Da perspectiva do candidato, independentemente de coligaçáo, disputar votos diretamente com um puxador ou com qualquer outro concorrente representa uma dificuldade a mais. Além disso, representa uma ineficiência do partido no emprego de recursos múltiplos com a finalidade de conquistar um mesmo eleitorado. Ainda que um candidato possa se beneficiar da votaçáo de um puxador de votos e, por conseguinte, ser eleito, consideramos que a maximização dos votos de um candidato e a conquista de um cargo a partir de votos nominais próprios trazem mais segurança à posiçáo do indivíduo, inclusive quanto a futuras candidaturas eleitorais.

A lógica da apresentação de dados seguirá a ordem dos partidos apresentada acima com dados sobre todas as candidaturas e com um recorte daquelas que receberam mais de 30 mil votos para realçar a competição intrapartidária entre as mais viáveis eleitoralmente. Escolhemos esse recorte porque ele nos permite focar naqueles candidatos com maior desempenho diminuindo a inflação causada por correlaçóes altas entre candidatos sem grandes chances de eleição. Além disso, o valor de 30 mil votos se aproxima, para o Estado de São Paulo em 2014, dos 10\% dos votos vá$\operatorname{lidos}^{14}$ estabelecidos pela nova regra eleitoral aprovada em 2015 (Lei no $13.165 / 2015)$.

A Tabela 1 apresenta a descrição das médias, das medianas e dos desvios-padróes das correlaçóes de votos encontradas para os candidatos dos partidos analisados aqui. É possível observar essas medidas para o conjunto de candidatos em geral do partido e para os candidatos com mais de 30 mil votos. No conjunto geral de candidatos, as médias e as medianas das correlações são baixas, não obstante apresentem variação, conforme os desvios-padrôes apresentados. A maior parte das combinaçôes de pares de candidatos nos partidos tem correlação de votação por zona eleitoral muito

14 Em 20I4, o quociente eleitoral do Estado de São Paulo para Deputado Federal foi de 303.738 votos após a retotalização do resultado das eleições pelo Tribunal Regional Eleitoral de São Paulo. Disponível em: http://www. tre-sp.jus.br/imprensa/noticias-tre-sp/20 I4/Dezembro/retotalizacoes-alteram-lista-de-deputados-estaduais-efederais-eleitos. Acesso em: 10 jan. 2019. 
próxima de zero. Os desvios-padróes, no entanto, são maiores, mostrando que, embora exista grande quantidade de valores próximos de zero, também há casos de correlaçốes mais fortes. Observamos, ainda, que as médias das correlaçôes de votos no PSDB e no PT são ligeiramente maiores que aquelas de candidatos no PR e no PRB. No conjunto de candidatos com mais de 30 mil votos, esse retrato muda. As médias das correlaçôes de votos entre esses candidatos, embora bastante baixas, são maiores no PRB e no PT, seguidos do PR e do PSDB. Isso pode indicar que alguns partidos, como o PSDB, podem ter sido mais eficientes para coordenar os esforços dos candidatos mais competitivos entre si, todavia a coordenação não tenha sido a mais eficiente no conjunto geral de candidaturas.

A seguir, vamos explorar mais detidamente as correlaçóes dos candidatos de cada um desses quatro partidos.

Tabela I - Média, mediana e desvio-padrão das correlações dos votos por zona eleitoral de candidatos de quatro partidos para Deputado Federal 2014 - SP*

\begin{tabular}{lcccccc}
\hline \multirow{2}{*}{ Partido } & \multicolumn{3}{c}{ Candidatos } & \multicolumn{3}{c}{ Candidatos com mais de 30 mil votos } \\
\cline { 2 - 7 } & Média & Mediana & $\begin{array}{c}\text { Desvio- } \\
\text { padrão }\end{array}$ & Média & Mediana & $\begin{array}{c}\text { Desvio- } \\
\text { padrão }\end{array}$ \\
\hline PSDB & 0,075 & 0,01 & 0,144 & 0,016 & $-0,02$ & 0,151 \\
PT & 0,057 & 0,01 & 0,120 & 0,069 & 0,00 & 0,147 \\
PRB & 0,028 & 0,0 & 0,096 & 0,102 & 0,04 & 0,231 \\
PR & 0,026 & 0,0 & 0,080 & 0,044 & $-0,01$ & 0,14 \\
\hline
\end{tabular}

${ }^{*}$ Correlações e estatísticas calculadas a partir de dados extraídos do Repositório de Dados Eleitorais do Tribunal Superior Eleitoral (2019).

Fonte: Elaborada pelos autores (2019).

\section{PSDB}

Na eleição de 2014, o PSDB teve 54 candidatos que receberam somados mais de 3,1 milhóes de votos, sendo Eleni Santos a candidata menos votada (85 votos) e Bruno Covas o candidato que mais recebeu sufrágios (352 mil votos). A correlação entre as votaçóes desses 54 candidatos por zona eleitoral pode ser verificada no Gráfico 1. 
Gráfico I - Grade de correlações dos votos por zona eleitoral dos candidatos do PSDB para deputado federal 2014 - SP*

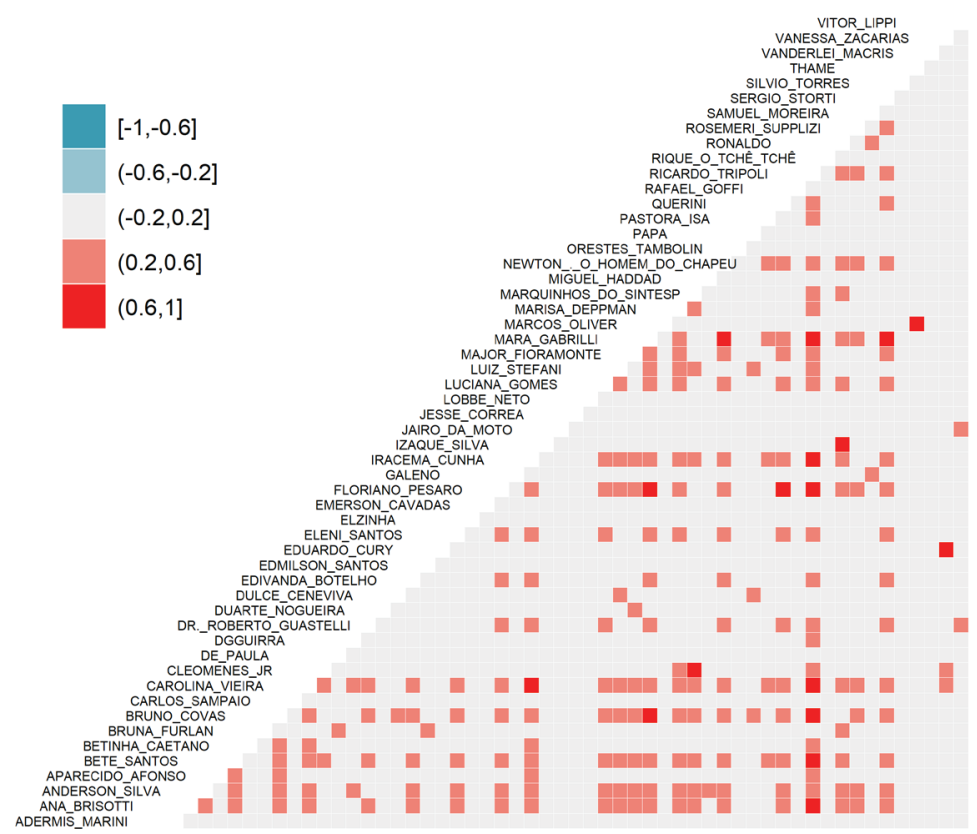

${ }^{*}$ Correlações e estatísticas calculadas a partir de dados extraídos do Repositório de Dados Eleitorais do Tribunal Superior Eleitoral (2019).

Fonte: Elaborado pelos autores (2019).

O gráfico 1 apresenta uma matriz das correlaçóes por zona eleitoral das votaçóes dos candidatos a deputado federal do PSDB. Cada quadrado representa a correlação entre a votação de dois candidatos. Os quadrados à direita do nome do candidato são as correlaçóes com os candidatos cujo nome apareceu antes dele se a grade é lida de cima para baixo. Os quadrados da linha abaixo do nome do candidato são as correlaçóes com os candidatos cujo nome vem após o dele. As correlaçóes foram divididas em cinco categorias ${ }^{15}$, como é apresentado pela legenda do gráfico. Correlaçóes negativas fortes têm cor azul mais escuro, correlaçóes negativas moderadas

15 Os símbolos "( " e ")" indicam que o valor não está contido pela categoria, já os símbolos "[" e "]" indicam que o valor está contido na categoria. 
possuem cor azul mais claro, correlaçôes fracas ou ausência de correlação estão em cinza-claro, correlações positivas moderadas são representadas pelo vermelho mais claro e, por fim, correlaçóes positivas fortes ficam em vermelho-escuro.

Dos 54 candidatos, 18 apresentaram alguma forma de correlação forte, ou seja, maior que 0,6 (33,3\% do total). O que significa que um terço dos candidatos teve algum outro pleiteante disputando diretamente votos com ele. Caso consideremos também as correlaçóes moderadas (acima de $0,2)$, esse número sobe para 41 (76\% do total). É importante notar que, apesar do alto valor, boa parte dos candidatos ou enfrentou apenas correlaçôes moderadas ( 23 ou 42,6\%) ou não enfrentou qualquer forma de correlação nos seus votos (13 ou $24 \%$ do total). Esta forma de olhar os dados foca na quantidade de candidatos que tiveram pelo menos um concorrente do mesmo partido com correlação de voto moderada ou forte.

Outra forma de olhar os dados é considerar que cada combinação de candidatos pode tomar um valor fraco, moderado ou forte e que é preciso levar em consideração todo esse espaço de variação na análise. Assim, podemos observar melhor a quantidade de correlaçóes moderadas e fortes que a lista partidária gerou. Das 1.431 correlaçóes produzidas pela combinação dois a dois dos 54 candidatos, apenas $17^{16}$ (1,2\% do total) apresentaram valor considerado alto (acima de 0,6), 226 (15,8\% do total) com correlação moderada (entre 0,2 e 0,6$)$ e 1.188 (83\% do total) com correlação fraca (entre 0,2 e -0,2). Essa distribuição de correlaçóes entre as votações dos candidatos indica que há alguma competição intrapartidária, mas ela não parece ser disseminada.

Essa diferença entre as duas formas de ver os dados decorre do fato de que, como mostram as grades de correlação, as combinações de correlaçôes com valores altos tendem a acontecer com o mesmo grupo de candidatos. Dessa forma, os 18 candidatos que tiveram alguma correlação forte com outro representam apenas 17 combinaçôes. Não obstante, por mais que, proporcionalmente, essas correlaçôes fortes atinjam uma pequena

I6 Esse número é menor que os 19 candidatos apresentados acima uma vez que se refere às combinações. Uma combinação envolve dois candidatos. Duas combinações podem envolver quatro candidatos se não existir repetição ou, três, caso o mesmo candidato esteja nas duas combinações. 
parte das combinaçóes possíveis entre esses candidatos, do ponto de vista do indivíduo, a existência de uma única combinação caracterizada por correlação forte indica competição direta com um correligionário. No entanto, considerar o número de combinaçóes como unidade, aumenta a quantidade de relaçôes possíveis e permite observar maior variação já que um mesmo candidato pode estar envolvido em correlaçóes de diferentes intensidades com outros candidatos.

Como os partidos que disputam vagas lançam candidatos muito diversos, é preciso verificar a correlação entre os candidatos considerados de maior potencial. Para isso, no Gráfico 2 apresentamos a mesma grade de correlaçóes do Gráfico 1; mas, somente entre os candidatos que obtiveram mais de 30 mil votos.

Gráfico 2 - Grade de correlações dos votos por zona eleitoral dos candidatos do PSDB (mais de 30 mil votos) para deputado federal 2014 - SP*

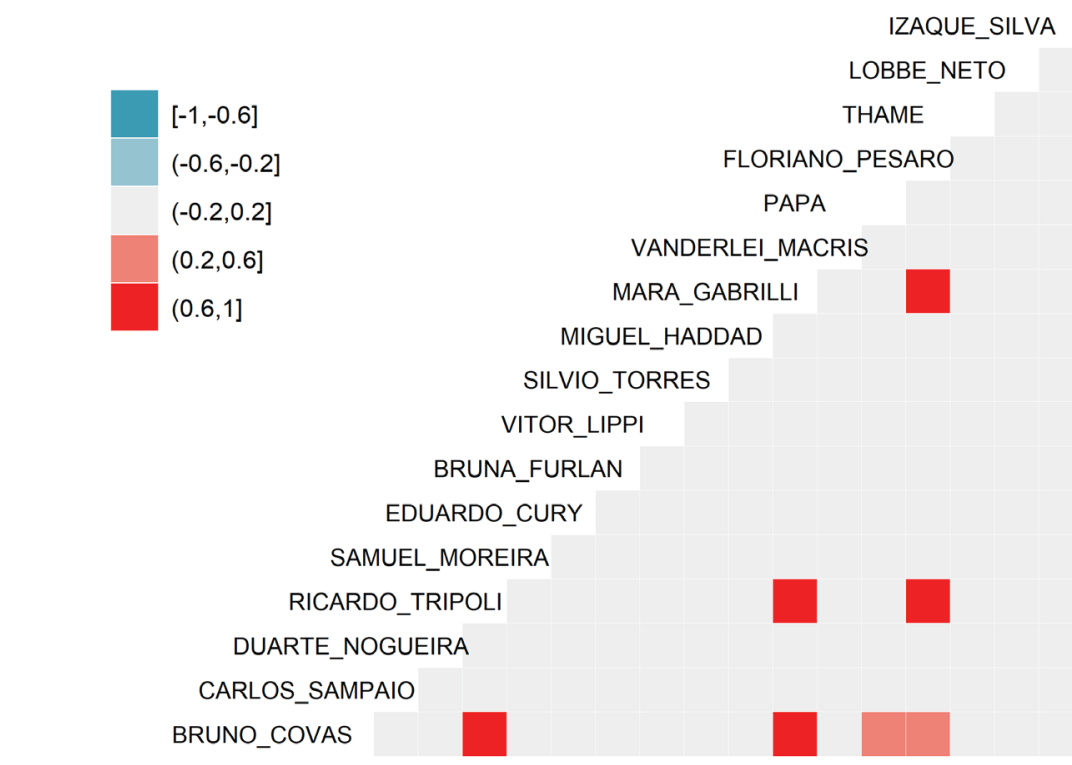

*Correlações e estatísticas calculadas a partir de dados extraídos do Repositório de

Dados Eleitorais do Tribunal Superior Eleitoral (2019).

Fonte: Elaborado pelos autores (2019). 
Dos 54 pleiteantes a deputado federal disputando pelo PSDB, 17 obtiveram mais de 30 mil votos. Desses, quatro apresentaram pelo menos outro candidato com votação que possui correlação forte com a sua e um apresentou apenas uma correlação moderada. O cenário da disputa de votos entre aqueles nomes que podem ser considerados da elite do partido é de menor competição intrapartidária que entre todos os candidatos. Entre os primeiros, apenas cinco apresentaram correlação moderada ou forte com outro candidato do mesmo grupo.

Considerando as 136 possíveis combinaçóes entre esses candidatos e as respectivas correlaçóes de voto, apenas cinco (3,7\% do total) apresentam coeficiente acima de 0,6 e apenas duas (1,5\%) apresentam correlação moderada. Não obstante, a busca de votos entre a elite do partido pareça ser mais eficiente, é preciso ressaltar que há altas correlaçóes entre esse grupo, por exemplo, a correlação entre as votaçóes de Mara Gabrilli e Floriano Pesaro $(0,88)$. Mara Gabrilli também apresenta correlaçóes fortes com Ricardo Tripoli $(0,69)$ e Bruno Covas $(0,67)$. Esses últimos são protagonistas de uma correlação de 0,66 entre si e, por fim, Floriano Pesaro e Ricardo Tripoli também têm votaçôes altamente correlacionadas $(0,62)$.

No caso do PSDB em SP, as candidaturas de Gabrilli, Tripoli e Pesaro levantam uma questão interessante. Pesaro foi último eleito pelo PSDB, com 113 mil votos. O último eleito pela coligação foi Alexandre Leite do DEM, com 109 mil votos e, o primeiro suplente, Thame do PSDB, com 106 mil votos. Isso mostra que, embora tenha tido sucesso em se eleger, a votaçáo de Pesaro ficou relativamente próxima do limite para garantir a vaga. Tendo apresentado correlaçóes fortes com outros candidatos mais bem posicionados na lista do PSDB, Pesaro disputou, potencialmente, os mesmos eleitores com esses nomes, posicionando-o de maneira arriscada frente a esses últimos. É interessante notar que Pesaro, Gabrilli e Tripoli defendem plataformas de valores pós-materialistas; porém, cada um deles com uma ênfase específica (Gabrilli com os direitos de minoria das pessoas com deficiência, Pesaro com os direitos de minoria LGBT e Tripoli com questôes ambientais). As correlaçóes altas de suas votaçôes e a complementaridade de suas plataformas fazem pensar que esses candidatos estariam dividindo um mesmo eleitorado potencial. Contudo, resta saber se, caso algum deles se ausentasse da eleição, seus eleitores migrariam para os 
outros dois candidatos ou não. Se essa migração ocorresse, isso evidenciaria um excesso de candidatos para mobilizar os mesmos eleitores nas respectivas zonas eleitorais. Do ponto de vista dos candidatos, isso representaria uma dificuldade a mais na busca de maximizar seus votos. Nesse cenário, do ponto de vista dos dirigentes, isso também seria um sinal de ineficiência; afinal, o partido poderia alcançar o mesmo resultado com um esforço menor e parte dos recursos poderia ser mais bem aproveitada em outras candidaturas. Entretanto, caso náo houvesse a migraçáo dos votos de um candidato ausente para outro de plataforma similar, esse fato poderia mostrar que os candidatos, apesar de serem relativamente semelhantes, atendem em sua multiplicidade a subgrupos de eleitores dentro de cada zona de maneira exclusiva. Sendo assim, seria mais vantajoso para o partido conservar os três candidatos ou procurar recrutar outro candidato que agregasse tais plataformas em um único esforço.

Resta saber se esses indicadores de competição eleitoral se mantêm similares para outros partidos.

\section{PT}

O Partido dos Trabalhadores, em 2014, teve 68 candidatos que receberam pouco menos de 2,4 milhóes de votos em conjunto. A candidatura que teve menos votos foi a de Geraldinho, "O iluminado", com 356 votos. E Andrés Sanchez recebeu mais votos, com cerca de 170 mil votos. As 2.278 correlaçóes entre esses 68 candidatos podem ser vistas no gráfico 3 . 
Gráfico 3 - Grade de correlações dos votos por zona eleitoral dos candidatos do PT para deputado federal $2014-$ SP $^{*}$

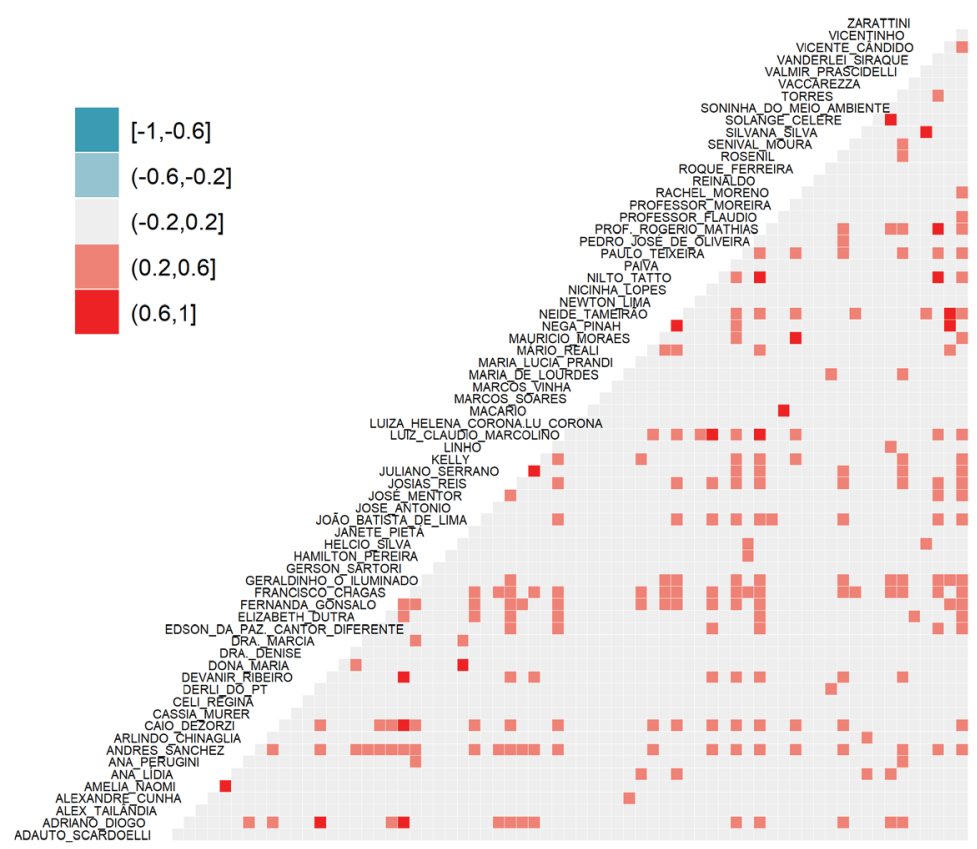

*Correlações e estatísticas calculadas a partir de dados extraídos do Repositório de

Dados Eleitorais do Tribunal Superior Eleitoral (2019).

Fonte: Elaborado pelos autores (2019).

Dos 68 candidatos presentes na lista do PT, 25 (36,8,2\%) tiveram pelo menos outro candidato com correlação de votos considerada forte, $29(42,7 \%)$ apresentaram apenas correlaçôes moderadas e 14 (20,6\%) não tiveram qualquer correlação moderada ou forte com seus votos. $\mathrm{O}$ percentual de candidatos que tiveram pelo menos uma correlação moderada ou forte com outro candidato é similar ao encontrado para o PSDB.

Considerando todas as 2.278 combinaçóes e suas correlaçóes, apenas $19(0,8 \%$ do total) apresentaram coeficiente maior que 0,6, $219(9,6 \%)$ apresentaram correlação moderada e as 2.040 (89,6\%) combinações restantes apresentaram correlaçóes fracas ou inexistentes. Olhando por esse indicador, apesar de mais candidatos envolvidos, os candidatos da lista 
do PT parecem ter experimentado uma competição intrapartidária menor que os candidatos da lista do PSDB, já que somente 10,4\% das combinaçóes possíveis apresentaram correlação moderada ou forte, enquanto no PSDB foram $17 \%$.

O gráfico 4, apresentado a seguir, mostra as correlaçóes dos votos por zona eleitoral dos 27 candidatos do PT que obtiveram mais de 30 mil votos. Nele, é possível observar que, também entre a elite dos candidatos do partido, não predomina a competição intrapartidária forte. Desses 27 , seis tiveram pelo menos uma correlação forte com a votaçáo de outro candidato e outros 13 apresentaram apenas correlaçóes moderadas. Isso conferiu, ao grupo de candidatos com mais de 30 mil votos, o mesmo padrão de cerca de $4 / 5$ de candidatos com correlaçóes moderadas ou fortes apresentada pelo grupo geral. Diferentemente do PSDB, a competição entre os candidatos no PT não apresentou queda quando mudamos o foco de todos os candidatos para aqueles com mais de 30 mil votos. As correlaçóes, no entanto, foram em sua maioria moderadas.

Dentre as 351 combinações possíveis de candidatos, somente cinco $(1,4 \%)$ apresentaram correlaçóes consideradas fortes. As correlaçóes moderadas, todavia, foram um pouco mais frequentes na elite do partido, com 48 casos de 351 (13,7\%). Apesar de não representarem ocorrências muito frequentes, há casos de correlaçóes fortes entre as votaçóes, por exemplo: Nilto Tatto e Vicente Cândido $(0,83)$, ou de Adriano Diogo e Francisco Chagas (0,75).

A título de exemplo, levantamos duas situaçóes que nos chamaram a atenção no PT. Uma delas são as correlaçôes fortes entre três suplentes do partido. Na coligação PT-PCdoB, Devanir Ribeiro, sindicalista, foi o décimo suplente com 60 mil votos, Francisco Chagas, sociólogo, foi o décimo primeiro suplente com 58 mil votos e Adriano Diogo, geólogo e sanitarista, foi o décimo segundo suplente com 54 mil votos. A correlação das votaçóes de Francisco e de Adriano foi da ordem de 0,75, a de Adriano e de Devanir foi de 0,68, e a de Devanir e de Francisco foi de 0,6. Caso houvesse coordenação entre esses três suplentes, possivelmente, um deles poderia estar na lista de eleitos, pois suas votaçóes individuais somadas e fortemente correlacionadas nas zonas eleitorais ultrapassam razoavelmente 
o número de votos do último eleito da coligação, José Mentor, com cerca de 82 mil votos. Ceteris paribus, se o candidato mais mal posicionado dos três, Adriano, fosse capaz de obter $15 \%$ dos votos dos outros dois candidatos, isso já seria suficiente para posicioná-lo dentre os eleitos. Contudo, para isso, seria necessário que os apelos específicos deles pudessem ser resumidos sob uma mesma plataforma. Ainda assim, reconhecemos que as decisóes envolvidas em torno de uma coordenação desse tipo seriam complexas, afinal, os três candidatos alcançaram desempenho semelhante.

A análise dos casos do PSDB e do PT trata de partidos tradicionais no estado de São Paulo, providos, nesse local, de estruturas partidárias organizadas. É possível argumentar que esses fatores facilitariam a existência de alguma coordenação na montagem da lista de candidatos com a finalidade de diminuir a competição intrapartidária. Não obstante, seguindo os achados de Guarnieri (2011) sobre a força dos partidos fracos, talvez a existência dessas estruturas partidárias dificulte a centralização de poderes no partido e, por conseguinte, a coordenação na formação da lista. Para verificar se os achados sobre a extensão e a intensidade da competiçáo intrapartidária são enviesados pela escolha desses casos, apresentamos também os dados para o PRB e o PR, exemplos menos tradicionais de organização partidária. 
Gráfico 4 - Grade de correlações dos votos por zona eleitoral dos candidatos do PT (mais de 30 mil votos) para deputado federal 2014 - SP*

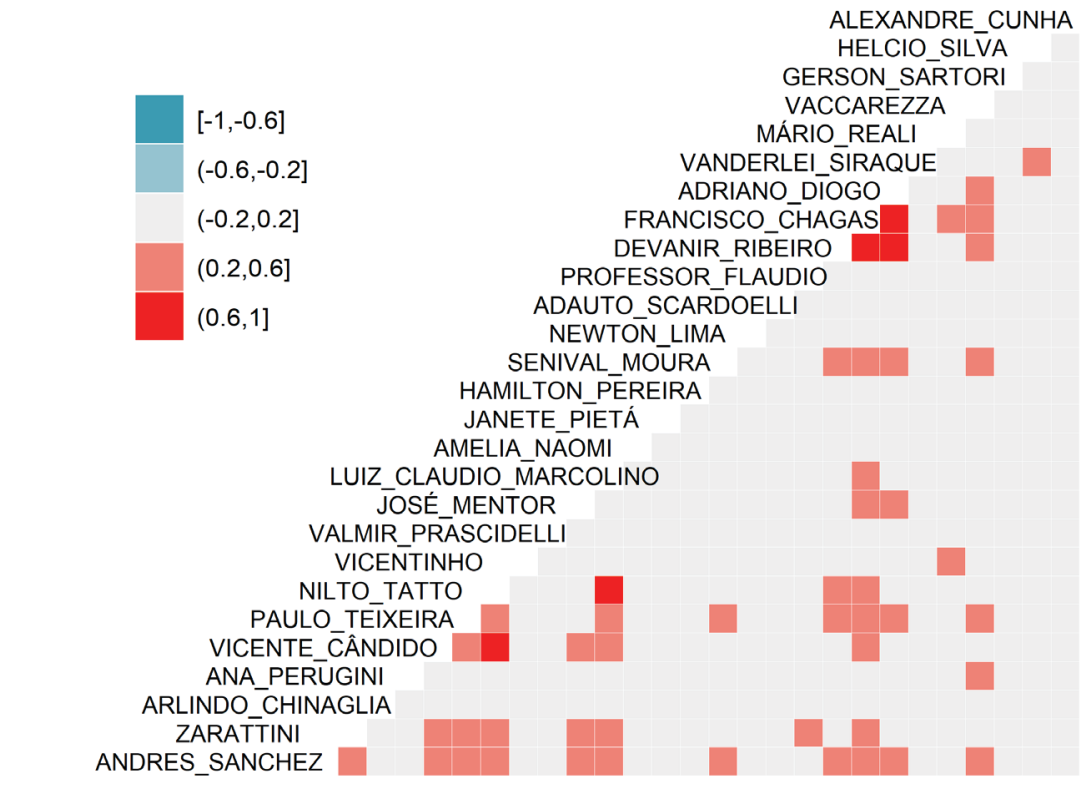

${ }^{*}$ Correlações e estatísticas calculadas a partir de dados extraídos do Repositório de

Dados Eleitorais do Tribunal Superior Eleitoral (2019).

Fonte: Elaborado pelos autores (2019).

\section{PRB}

O PRB lançou 96 candidatos que obtiveram pouco mais de 2,2 milhóes de votos. Dessa maneira, o partido apresentou uma quantidade de candidaturas consideravelmente maior que o PT (68) e que o PSDB (54). Ermy Andrade recebeu apenas 41 votos, sendo o menos votado do partido, e Celso Russomanno foi o recordista de votos, com mais de 1,5 milhóes. O gráfico 5 apresenta as 4.560 correlações resultantes das combinaçóes possíveis de candidatos. 
Gráfico 5 - Grade de correlações dos votos por zona eleitoral dos candidatos do PRB para deputado federal $2014-$ SP $^{*}$

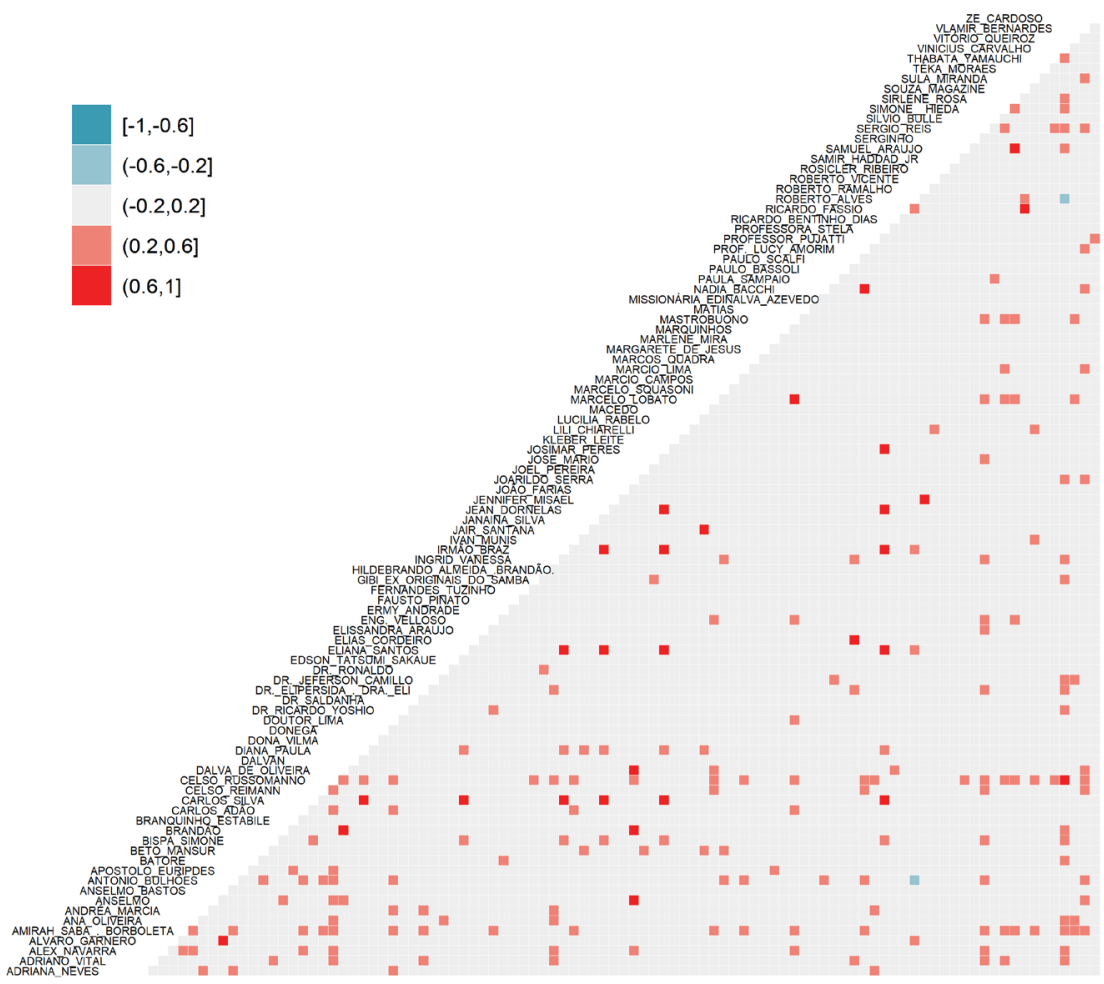

*Correlações e estatísticas calculadas a partir de dados extraídos do Repositório de Dados Eleitorais do Tribunal Superior Eleitoral (2019).

Fonte: Elaborado pelos autores (2019).

Considerando os 96 candidatos lançados pelo partido, 29 (30,2\%) apresentaram pelo menos outro concorrente que teve correlação de votos considerada forte. A maior parte, no entanto, 46 candidatos $(47,9 \%)$, teve ao menos uma correlaçáo moderada apenas; enquanto os outros 21 $(21,9 \%)$ tiveram apenas correlaçóes fracas. O PRB seguiu o padrão do PSDB e do PT de cerca de um terço de candidatos com pelo menos um competidor direto pelo voto e 4/5 com competição moderada.

Das 4.560 combinaçóes possíveis, apenas 29 apresentaram correlaçóes consideradas fortes $(0,6 \%$ do total) e 193 apresentaram correlaçóes 
moderadas (4,2\%). Apesar de nove das 29 correlaçóes fortes serem acima de 0,9 , no geral, o partido não parece ter colocado muitos de seus candidatos para competirem pelo mesmo voto. É interessante notar que o PRB é o primeiro dos partidos analisados até aqui a apresentar correlaçóes negativas moderadas entre os pares de candidatos Antônio Bulhóes e Roberto Alves $(-0,26)$ e Roberto Alves e Vinicius Carvalho $(-0,23)$.

Apesar da presença de um grande puxador de votos, o desempenho dos outros candidatos do partido parece ter sido preservado do embate direto com esse último. A única correlação forte entre as votaçóes de Russomanno e de outro candidato ocorreu com um nome que conseguiu se eleger com mais de 80 mil votos. Praticamente todas as correlaçóes, entre a votação de Russomanno e de outros candidatos, classificadas como moderadas aconteceram com nomes de desempenho pouco expressivo, que obtiveram menos de 10 mil votos, número relativamente distante da votação do primeiro suplente do partido - 21 mil votos. As duas exceçóes ficam por conta das correlaçóes moderadas (0,51 e 0,5, respectivamente) com as votações de Antônio Bulhões, eleito com 137 mil votos, e de Sérgio Reis, eleito com 45 mil votos. Em resumo, a correlaçáo forte ou moderada de Russomanno com candidatos eleitos do PRB não impediu que as votaçóes desses últimos ultrapassassem $10 \%$ do quociente eleitoral. Apesar disso, o PRB teve um candidato eleito em 2014, Fausto Pinato, que náo ultrapassaria a regra dos $10 \%$ do quociente eleitoral criada em 2015 pois recebeu apenas 22 mil votos. ${ }^{17}$

17 A correlação entre a votação de Fausto Pinato e Celso Russomanno foi de apenas -0,04, todavia. 
Gráfico 6 - Grade de correlações dos votos por zona eleitoral dos candidatos do PRB (mais de 30 mil votos) para Deputado Federal 2014 - SP*
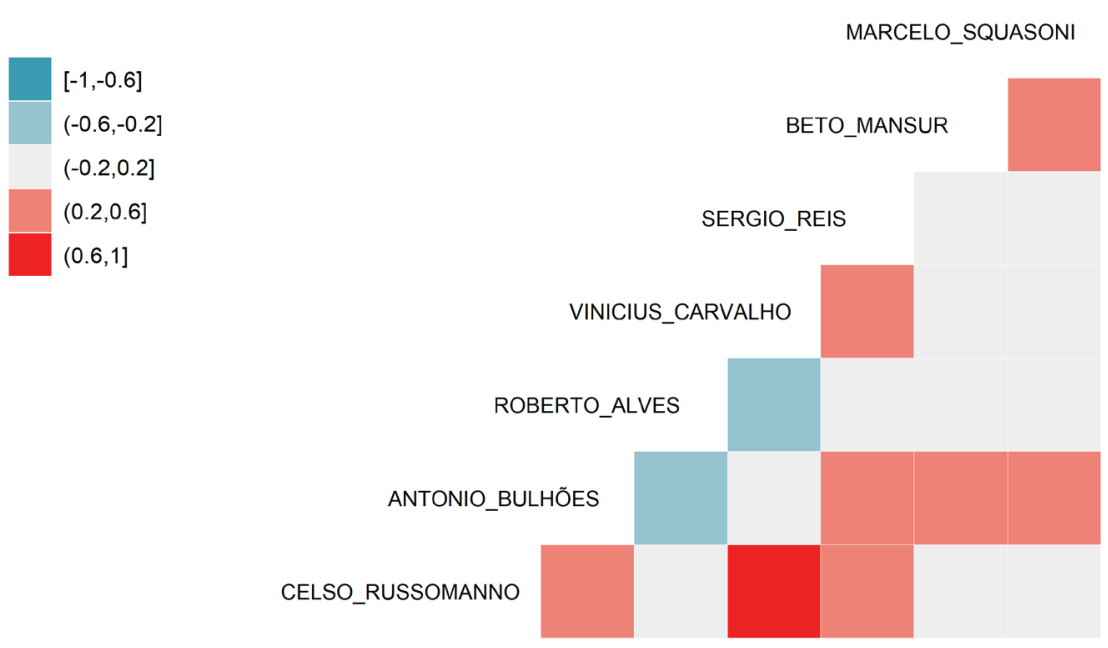

${ }^{*}$ Correlações e estatísticas calculadas a partir de dados extraídos do Repositório de Dados Eleitorais do Tribunal Superior Eleitoral (2019).

Fonte: Elaborado pelos autores (2019).

Dos 96 candidatos do PRB, apenas sete alcançaram mais de 30 mil votos. Desses sete, dois apresentaram correlação positiva forte entre as suas votaçóes, outros quatro tiveram pelo menos uma correlação positiva moderada e apenas dois, Roberto Alves e Antonio Bulhôes, apresentaram correlação moderada negativa entre si.

Como o gráfico 6 mostra, considerando as combinaçôes possíveis, a correlação entre os votos de dois deles, Celso Russomanno e Vinícius Carvalho, foi forte $(0,63)$. Outras sete combinaçôes $(33,3 \%)$ apresentaram correlaçóes moderadas positivas e duas, como afirmamos anteriormente, apresentaram correlaçáo moderada negativa (9,5\%\%). Pelo número de combinaçóes com correlação moderada ou forte da elite do partido, é possível notar que existiu mais competição intrapartidária dentro do PRB se comparada à do PT e do PSDB; mas, não deve ser classificada como intensa, já que envolveu mais correlaçóes moderadas do que fortes. 


\section{PR}

O Partido da República teve 33 candidatos a deputado federal em São Paulo que receberam, em conjunto, pouco menos de 1,7 milhóes de votos. Essa votação se concentrou principalmente no candidato Tiririca que recebeu mais de um milhão de votos. Na eleição anterior, em 2010, o PR já havia optado por lançar uma lista relativamente enxuta de candidatos e concentrar recursos, principalmente o tempo de televisão, no candidato Tiririca (SOUZA, 2016). Portanto, o menor número de candidatos lançados pelo partido possivelmente já sinaliza um esforço de coordenação. A grade de correlaçóes das 528 combinaçóes possíveis entre os candidatos é apresentada no gráfico 7 .

Gráfico 7 - Grade de correlações dos votos por zona eleitoral dos candidatos do PR para deputado federal $2014-$ SP $^{*}$

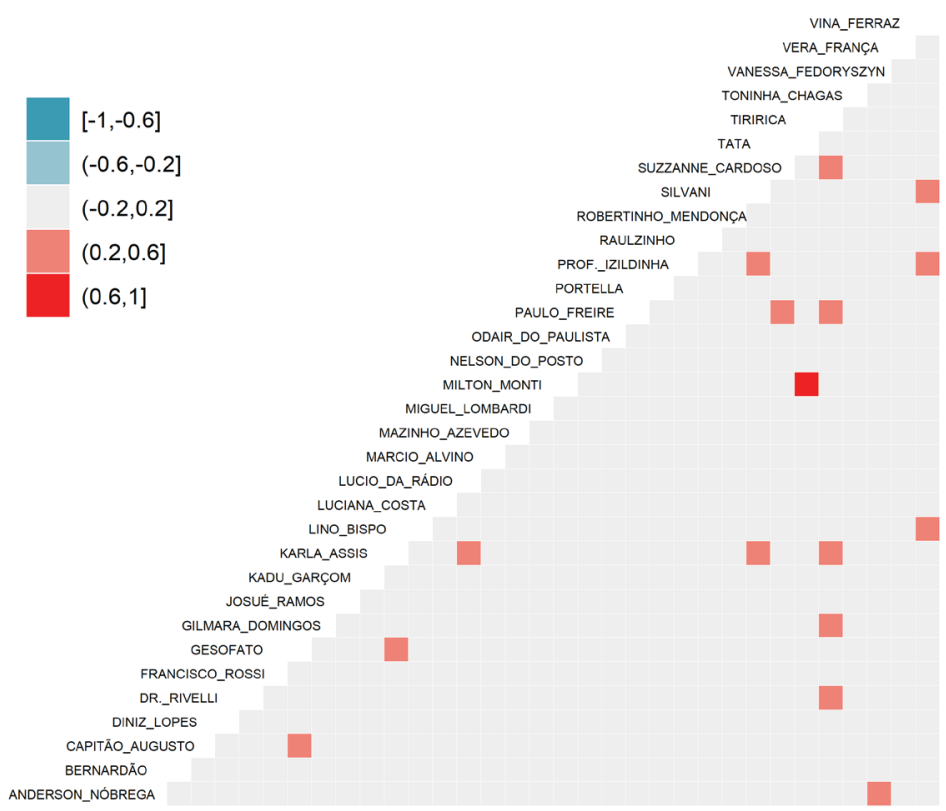

${ }^{*}$ Correlações e estatísticas calculadas a partir de dados extraídos do Repositório de

Dados Eleitorais do Tribunal Superior Eleitoral (2019).

Fonte: Elaborado pelos autores (2019). 
Dentre os 33 candidatos, apenas dois $(6,1 \%)$ apresentaram entre si uma correlação considerada forte e outros 15 (45,5\%) apresentaram apenas correlação moderada com pelo menos algum outro candidato do partido. Os outros $16(48,5 \%)$ não obtiveram correlação ou somente correlação fraca com outro candidato. Assim, o PR lançou a lista de candidatos que teve menor competição intrapartidária se considerarmos essa forma de mensuração.

Das 528 combinaçóes possíveis de candidaturas lançadas pelo PR, apenas uma $(0,2 \%)$ apresentou correlação forte, sendo o coeficiente 0,88 entre Milton Monti e Tata. Outras 16 combinaçóes (2,8\%) apresentaram correlaçôes moderadas. Essa distribuição de correlaçôes de votos por zona eleitoral entre os candidatos indica que a disputa intrapartidária pelo mesmo voto foi baixa. O gráfico 8, que mostra os seis candidatos do PR com mais de 30 mil votos, reforça essa percepção de eficiência, já que há apenas uma correlação moderada entre as votações de Tiririca e Paulo Freire (6,7\% das combinaçôes possíveis para o grupo de elite).

No caso de Tiririca, o puxador de votos do PR, apesar de muito bem votado, não impediu o bom desempenho de outros candidatos do partido porque a correlaçáo de seus votos com os de outros nomes bem colocados no PR foi fraca. A única exceção, uma correlação moderada $(0,55)$ entre os votos de Tiririca e de Paulo Freire, não se tornou um obstáculo à eleição desse último com 113 mil votos. Inclusive, as poucas correlaçóes moderadas dos votos de Tiririca com outros candidatos do PR ocorreram com quatro nomes de pouca expressáo que tiveram menos de mil votos. Ademais, os dirigentes parecem ter acertado na coordenação, pois a correlação entre os votos de outros candidatos do partido entre si foram pouco frequentes. A partir da mudança de regras da reforma de 2015, o desafio passa a ser desconcentrar os votos do puxador para náo expor demasiadamente o último eleito da lista a perder uma vaga por conta da nova regra de desempenho individual de $10 \%$ do quociente eleitoral. 
Gráfico 8 - Grade de correlações dos votos por zona eleitoral dos candidatos do PR (mais de 30 mil votos) para deputado federal 2014 - SP*
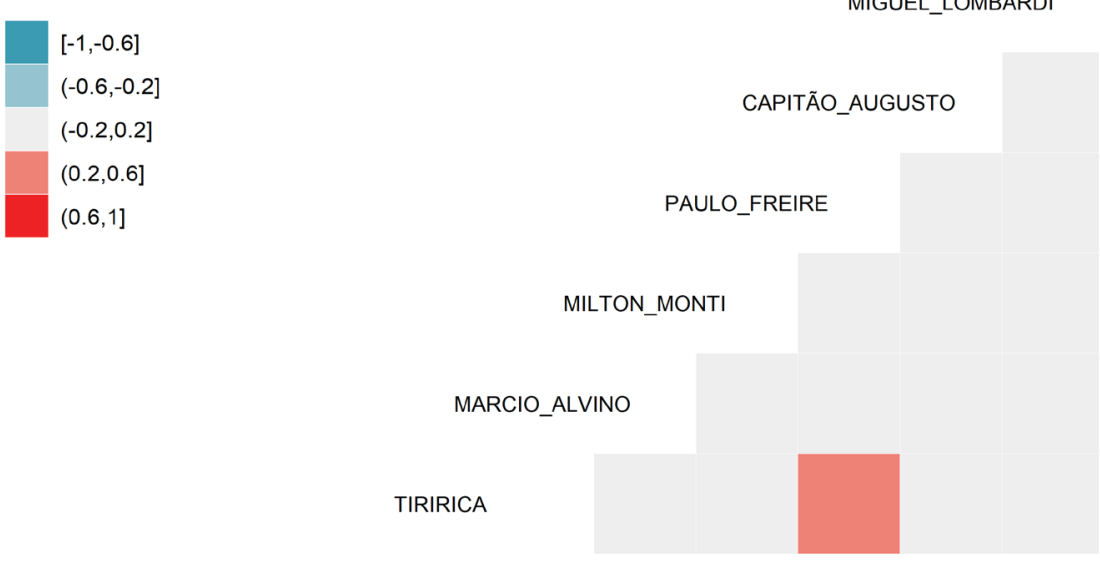

*Correlações e estatísticas calculadas a partir de dados extraídos do Repositório de Dados Eleitorais do Tribunal Superior Eleitoral (2019).

Fonte: Elaborado pelos autores (2019).

A análise dos quatro partidos indica que a expectativa de haver intensa competição intrapartidária nas eleiçóes proporcionais brasileiras deve ser tomada como uma hipótese que ainda precisa de comprovação empírica e não como algo que decorre diretamente das regras eleitorais. Caso tomemos a hipótese da competição intrapartidária como uma afirmação de que se espera que tenhamos muitos candidatos de um mesmo partido disputando o mesmo voto, utilizar correlaçóes das votaçóes dos candidatos por zona eleitoral pode ser uma forma empírica de se aproximar da questão. Candidatos que possuem votaçóes mais altas nas mesmas zonas eleitorais terão suas votaçóes correlacionadas e estaráo, em princípio, competindo pelo mesmo eleitor-alvo. A agregaçáo de vários candidatos competindo entre si no mesmo partido seria um indicador de uma competição intrapartidária alta.

Parte da dificuldade em considerar se os dados desse estudo indicam alta competição intrapartidária está em definir o que seriam níveis altos, 
médios e baixos desse conceito cuja operacionalização, em geral, inexiste. A Tabela 2, a seguir, sumariza os achados desse artigo sobre a proporção de candidatos envolvidos e de combinaçóes possíveis que foram classificadas como correlaçóes altas ou moderadas por partido. Nela, é possível verificar que o PSDB apresentou a maior proporção de combinaçóes de candidaturas caracterizadas por correlaçóes de votos moderadas ou fortes. Essa soma, no entanto, chegou a apenas $17 \%$ das combinaçôes possíveis e as correlaçóes foram principalmente moderadas. O PT apresentou 10,4\% das combinaçóes de candidaturas possíveis com correlaçóes de votos altas ou moderadas, enquanto o PRB apresentou 4,8\%. O PR parece ter montado a lista de candidatos mais eficiente, já que as combinaçóes possíveis apresentaram correlaçóes de votos altas ou moderadas em apenas 3\% delas.

Tabela 2 - Combinações de candidaturas com correlações altas e moderadas por partido*

\begin{tabular}{|c|c|c|c|c|c|c|}
\hline \multirow[b]{2}{*}{ Partido } & \multicolumn{3}{|c|}{ Candidatos como unidade } & \multicolumn{3}{|c|}{ Combinações como unidade } \\
\hline & $\begin{array}{l}\text { Candidatos } \\
\text { com } \\
\text { correlação } \\
\text { alta (a) }\end{array}$ & $\begin{array}{l}\text { Candidatos } \\
\text { com } \\
\text { correlação } \\
\text { moderada } \\
\text { (b) }\end{array}$ & $\begin{array}{c}\text { Candidatos } \\
\text { com } \\
\text { correlações } \\
\text { altas e/ou } \\
\text { moderadas } \\
\text { (a+b) }\end{array}$ & $\begin{array}{l}\text { Combinações } \\
\text { com } \\
\text { correlação } \\
\text { alta (c) }\end{array}$ & $\begin{array}{l}\text { Combinações } \\
\text { com } \\
\text { correlação } \\
\text { moderada (d) }\end{array}$ & $\begin{array}{c}\text { Correlações } \\
\text { altas e } \\
\text { moderadas } \\
\text { (c+d) }\end{array}$ \\
\hline PSDB & $33,3 \%$ & $74 \%$ & $76 \%$ & $1,2 \%$ & $15,8 \%$ & $17 \%$ \\
\hline PT & $36,8 \%$ & $76,5 \%$ & $79,4 \%$ & $0,8 \%$ & $9,6 \%$ & $10,4 \%$ \\
\hline PRB & $30,2 \%$ & $47,9 \%$ & $78,1 \%$ & $0,6 \%$ & $4,2 \%$ & $4,8 \%$ \\
\hline PR & $6,1 \%$ & $45,5 \%$ & $51,5 \%$ & $0,2 \%$ & $2,8 \%$ & $3 \%$ \\
\hline
\end{tabular}

${ }^{*}$ Correlações e estatísticas calculadas a partir de dados extraídos do Repositório de Dados Eleitorais do Tribunal Superior Eleitoral (2019).

Fonte: Elaborada pelos autores (2019).

Considerando os candidatos envolvidos, a competição intrapartidária aparece nos dados, mas com diferentes gradações. Com exceção do PR, as listas partidárias colocaram cerca de um terço dos candidatos frente a pelo menos outro correligionário que teve votos correlacionados com os daqueles de forma forte. As ineficiências da lista, se tomarmos também como competição as correlaçóes moderadas, chegam a quase $80 \%$ dos candidatos do PSDB, PT e PRB. O PR montou a lista mais eficiente, já que pontua 
consistentemente abaixo dos outros nas duas formas de mensuração utilizadas aqui.

Como a literatura que produziu a expectativa teórica de alta competição intrapartidária não apresentou um indicador de referência e, portanto, o que seriam níveis altos ou baixos dessa competição, a afirmação sobre o quanto esses dados revelam da competição intrapartidária deve ser tomada com cuidado. A expectativa de intensa competição intrapartidária, todavia, na nossa opinião, não parece ter ocorrido nas quatro listas partidárias analisadas. Há, sim, variação na exposição de candidatos a concorrentes diretos. É possível discutir o quanto a aposta em puxadores de votos que geraram concentração de votos do PR, em Tiririca, principalmente, e do PRB, em Celso Russomanno, indicavam, até aquele momento, estratégias mais eficientes em evitar competição intrapartidária que as estratégias de partidos mais tradicionais no distrito, como PSDB e PT, que possuíam um leque maior de candidatos viáveis. Essa estratégia de concentrar votos em um grande puxador de votos parece ter trazido frutos para os dois partidos, enquanto PSDB e PT, ao que indica, foram menos eficientes na formação de suas listas. A estratégia de um grande puxador de votos implica um risco maior após a mudança da legislação, em 2015, que estabeleceu um desempenho mínimo individual de $10 \%$ do quociente eleitoral.

Para julgar as estratégias partidárias específicas, são necessários estudos de caso mais aprofundados. As correlaçôes fortes encontradas neste estudo, consideradas tanto pela quantidade de candidatos atingidos, quanto pela proporção das combinações totais possíveis atingidas, alcança uma menor parte das candidaturas. A forma de operacionalizar a ideia de competiçáo intrapartidária usada neste artigo, de usar correlaçôes entre a votação de diferentes candidatos por zona eleitoral, ainda precisa de mais debates sobre a sua robustez e adequação. Consideramos, no entanto, que ela é uma forma promissora de explorar os dados para analisar o problema da competição intrapartidária. 


\section{Considerações finais}

Este artigo se enquadra na literatura que busca explorar e discutir, a partir de dados eleitorais, as estratégias dos partidos nas eleiçóes proporcionais de lista aberta. A literatura que foca em incentivos do sistema eleitoral aponta que os partidos teriam grande dificuldade em organizar a disputa em distritos de magnitude tão grande quanto no Brasil nos quais os candidatos precisam buscar votos em suas campanhas individuais. A expectativa é de competição intrapartidária intensa.

Essa expectativa não considera, todavia, que é importante, para o partido e os candidatos, organizar a disputa para evitar desperdício de esforços e perda de cadeiras. Considerando a ideia de que candidatos possuem eleitores-alvo, competição intrapartidária existiria apenas se os pleiteantes disputassem o apoio desse mesmo conjunto de pessoas. A intensidade dessa disputa pode variar entre os partidos a depender da estratégia de formação da lista de candidatos.

Para analisar essa variação, examinamos as correlaçóes da votação por zona eleitoral dos candidatos a deputado federal de São Paulo de quatro partidos: PSDB, PT, PRB e PR. As correlaçóes de votação nos permitem verificar quais votações possuem uma distribuição espacial parecida, indicando disputa pelo mesmo eleitorado.

Os dados não revelam uma competição intrapartidária forte disseminada como era a expectativa da literatura e mostram diferentes estratégias eleitorais. No PSDB e no PT, a existência de múltiplos quadros viáveis na disputa gera certa ineficiência. Correlaçóes moderadas e fortes, nesses casos, poderiam ser mais bem coordenadas para garantir maior chance eleitoral para os candidatos envolvidos e fazer com que esses partidos, que disputaram a eleição coligados, obtivessem mais cadeiras. No PRB e no $\mathrm{PR}$, a figura de um candidato com votação extraordinária garantiu muitas cadeiras e, principalmente no caso do $\mathrm{PR}$ com Tiririca, não atrapalhou as chances de outros candidatos viáveis. Nesses casos, partidos menos tradicionais parecem ter conseguido organizar melhor a disputa por vagas na Câmara dos Deputados. 


\section{Referências}

AMES, B. Os entraves da Democracia no Brasil. Rio de Janeiro: Editora da Fundação Getúlio Vargas, 2003.

AVELINO, G.; BIDERMAN, C.; BARONE, L. S. Articulações intrapartidárias e desempenho eleitoral no Brasil. Dados, v. 55, n. 4, p. 987-1013, 2012.

BERGMAN, M. E.; SHUGART, M. S.; WATT, K. A. Patterns of intraparty competition in openlist \& SNTV systems. Electoral Studies, v. 2, n. 2, p. 321-333, 2013.

BOLOGNESI, B. A seleção de candidaturas no DEM, PMDB, PSDB e PT nas eleiçóes legislativas federais brasileiras de 2010: percepçóes dos candidatos sobre a formação das listas. Revista de Sociologia e Política, v. 21, n. 46, p. 45-68, 2013.

BRAGA, M. do S. Organizaçóes partidárias e seleção de candidatos no estado de São Paulo. Opiniáo Pública, v. 14, n. 2, p. 454-485, 2008.

BRAGA, M. do S.; AMARAL, O. E. do. Implicaçóes do processo de seleçáo de candidatos na competição partidária: o caso brasileiro. Rev. Sociol. Polit., v. 21, n. 46, p. 33-43, 2013.

BRASIL. Lei no 4.737, de 15 de julho de 1965. Institui o Código Eleitoral. Disponível em: http:// www.tse.jus.br/legislacao/codigo-eleitoral/codigo-eleitoral-1/codigo-eleitoral-lei-nb0-4.737-de-15de-julho-de-1965. Acesso em 16 nov. 2018.

BRASIL. Lei no 13.165, de 29 de setembro de 2015. Altera as Leis $n^{\circ}$ 9.504, de 30 de setembro de 1997, 9.096, de 19 de setembro de 1995, e 4.737, de 15 de julho de 1965 - Código Eleitoral, para reduzir os custos das campanhas eleitorais, simplificar a administração dos Partidos Políticos e incentivar a participação feminina. Disponível em: http://www.planalto.gov.br/ccivil_03/_ Ato2015-2018/2015/Lei/L13165.htm. Acesso em 16 nov. 2018.

BRASIL. Câmara dos Deputados. Bancada na eleiçáo. 2018. Disponível em: http://www2.camara. leg.br/deputados/liderancas-partidarias/bancadas/bancada-na-eleicao. Acesso em 16 nov. 2018.

CAIN, B.; FEREJOHN, J.; FIORINA, M. The Personal Vote: Constituency Service and Electoral Independence. Cambridge: Harvard Uni. Press, 1987. p. 45-67.

CAREY, J.; SHUGART, M. S. Incentives to Cultivate a Personal Vote: A Rank Ordering of Electoral Formulas. Electoral Studies, v. 14, n. 4, p. 417-439, 1995.

CARVALHO, N. R. E no início eram as bases: Geografia política do voto e comportamento legislativo no Brasil. Rio de Janeiro: Revan, 2003.

CHEIBUB, J. A.; FIGUEIREDO, A. M. C.; LIMONGI, F. Partidos políticos e governadores como determinantes do comportamento legislativo na Câmara dos Deputados, 1988-2006. Dados, v. 52, n. 2, p. 263-299, 2009.

CHHIBBER, P. K.; KOLLMAN, K. The Formation of National Party Systems: Federalism and Party Competition in Canada, Great Britain, India and the United States. Princeton: Princeton Uni. Press, 2004. p. 101-221. 
COX, G. W. The efficient secret: the Cabinet and the development of political parties in Victorian England. New York: Cambridge Uni. Press, 1987.

COX, G. W. SNTV and d'Hondt are 'equivalent'. Electoral Studies, v. 10, n. 2, p. 118-132, 1991.

FIGUEIREDO, A. M. C.; LIMONGI, F. Mudança Constitucional, Desempenho do Legislativo e Consolidação Institucional. Revista Brasileira de Ciências Sociais, v. 29, p. 175-200, 1995.

FIGUEIREDO, A. M. C.; LIMONGI, F. Executivo e Legislativo na nova ordem constitucional. Rio de Janeiro: Editora da Fundação Getúlio Vargas, 1999.

FOWERAKER, J. Review Article: Institutional Design, Party Systems and Governability - Differentiating the Presidential Regimes in Latin America. British Journal of Political Science, v. 28, n. 4, p. 651-676, 1998.

GRAÇA, L. F. G.; SOUZA, C. P. R. Uso estratégico de eleiçôes alternadas? Efeitos da candidatura para prefeito sobre a votação dos concorrentes ao cargo de deputado federal no Brasil. Opiniáo Pública, v. 20, n. 3, p. 326-345, 2014.

GUARNIERI, F. A força dos partidos “fracos”. Dados, v. 54, n. 1, p. 235-258, 2011.

LAGO, I. Magnitud de distrito y número de partidos. Revista Española de Ciencia Política, [S. 1.], p. 9-23, 2009.

LIMONGI, F; FIGUEIREDO, A. M. C. Partidos políticos na Câmara dos Deputados: 1989-1994. Dados, v. 38, n. 3, p. 497-523, 1995.

MAINWARING, S. Presidentialism, Multipartism and Democracy: The Difficult Combination. Comparative Political Studies, v. 26, n. 2, p. 198-228, 1993.

MAINWARING, S. Sistemas Partidários em Novas Democracias: O Caso do Brasil. Rio de Janeiro: Editora da Fundação Getúlio Vargas; Mercado Aberto, 1995. p. 51-96.

MAINWARING, S. Multipartism, Robust Federalism, and Presidentialism in Brazil. In: MAINWARING, S.; SHUGART, M. S. (Ed.). Presidentialism and Democracy in Latin America. Cambridge: Cambridge Uni. Press, 1997. p. 55-109.

NICOLAU, J. O Sistema Eleitoral de Lista Aberta no Brasil. Dados, v. 49, n. 4, p. 689-720, 2006. POWELL, G. B. Elections as Instruments of Democracy: Majoritarian and Proportional Visions. New Haven: Yale University Press, 2000.

SAMUELS, D. Determinantes do voto partidário em sistemas eleitorais centrados no candidato: evidências sobre o Brasil. Dados, v. 40, n. 3, p. 493-535, 1997.

SAMUELS, D. When Does Every Penny Count?: Intra-Party Competition and Campaign Finance in Brazil. Party Politics, v. 7, n. 1, p. 89-102, 2001.

SAMUELS, D. Political Ambition, Candidate Recruitment, and Legislative Politics in Brazil. In: MORGENSTERN, S.; P. SIAVELIS (Ed.). Pathways to Power in Latin America. State College: PSU Press, 2008. p. 76-91. 
SANTOS, A. M. Regras eleitorais importam? Modelos de listas eleitorais e seus efeitos sobre a competição partidária e o desempenho institucional. Dados, v. 49, n. 4, p. 721-749, 2006.

SHUGART, M. S.; CAREY, J. Presidents and Assemblies: Constitutional Design and Electoral Dynamics. New York: Cambridge Uni. Press, 1992.

SILVA, G. P. Uma avaliação empírica da competição eleitoral para a Câmara Federal no Brasil. Opiniáo Pública, v. 19, n. 2, p. 403-429, 2013.

SILVA, G. P. Mesmas instituiçóes, mesmos resultados? Comparando o efeito da competição eleitoral sobre os níveis de concentração de votos. Opinião Pública, v. 23, n. 3, p. 682-713, 2017.

SOUZA, C. P. R.; GRAÇA, L. F. G. Padróes de dependência espacial de votação e gastos de campanha: análise exploratória dos deputados federais e estaduais do Rio de Janeiro (2002 a 2010). Em Debate, Belo Horizonte, v. 4, n. 2, p. 53-62, 2012.

SOUZA, C. P. R. Candidatos diferentes, campanhas iguais? Um estudo sobre estratégias de gastos de campanha de candidatos a deputado federal no estado de São Paulo em 2010. Orientador: Jairo Nicolau. 2016. 239 f. Tese (Doutorado em Ciência Política) - Programa de Pós-Graduação em Ciência Política, Universidade do Estado do Rio de Janeiro, Rio de Janeiro, 2016.

TERRON, S. A Composição de Territórios Eleitorais no Brasil: Uma Análise das Votações de Lula (1989-2006). Orientador: Jairo Nicolau. 2009. 182 f. Tese (Doutorado em Ciência Política) - Programa de Pós-Graduaçấo em Ciência Política, Instituto Universitário de Pesquisas do Rio de Janeiro, Rio de Janeiro, 2009.

TRIBUNAL REGIONAL ELEITORAL DE SÃO PAULO (TRE-SP). Retotalizaçóes alteram lista de deputados estaduais e federais eleitos. 18 dez. 2014. Disponível em: http://www.tresp.jus.br/imprensa/noticias-tre-sp/2014/Dezembro/retotalizacoes-alteram-lista-de-deputadosestaduais-e-federais-eleitos. Acesso em: 10 jan. 2019.

TRIBUNAL SUPERIOR ELEITORAL (TSE). Repositório de Dados Eleitorais. 2019. Disponível em: http://www.tse.jus.br/eleicoes/estatisticas/repositorio-de-dados-eleitorais-1/ repositorio-de-dados-eleitorais. Acesso em: 10 jan. 2019. 


\section{Intraparty competition in elections for federal deputy: an exploratory study on São Paulo in 2014}

\section{Abstract}

This article addresses the issue of intraparty competition in open list proportional elections. Although the literature expects that Brazilian electoral rules encourage direct competition for votes among co-partisans, there are few efforts to measure the levels of this competition. Through voting correlations, by electoral zones, we discuss the degrees of spatial overlapping of candidacies within four parties in the race for the office of federal deputy in the state of São Paulo in 2014. We find variations in the levels of intraparty competition that indicate different coordination strategies in the selection of candidates. This variety shows that, besides the incentives of electoral rules, the agents' strategic responses to these rules should not be neglected when dealing with this theme.

Keywords: Elections. Federal deputies. Intraparty competition. Representation. São Paulo.

Recebido em 06/02/2019

Aprovado em 26/08/2019 